\title{
بعض العوامل المؤئرة على اتجاهات الزراع نحو المدارس الحقلية بمحافظة البحيرة
}

\author{
مها السيد حرحش ، على محمود عبد الحليم \\ قسم الاقتصاد والإرشاد الزراعي والتتمية الريفية - كلية الزراعة - جامعة دمنهور
}

Received: Feb. 11, 2017

Accepted: Mar. 18, 2017

الملخص

بيتهذف هذا البحث بصفة رئيسية التعرف على بعض العوامل المؤثرة على اتجاهات الزراع نحو الديارس الحقلية

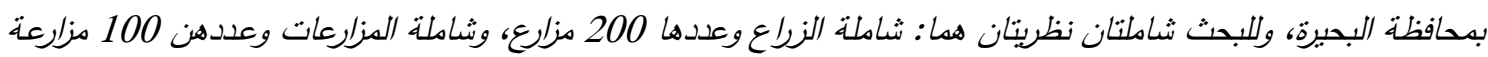
من الحاضرين للأنثطة الإشادية الزراعية للددارس الحقلية وعددها 12 مدرسة تم تنفيذها في أربع مراكز إدارية بدحافظة

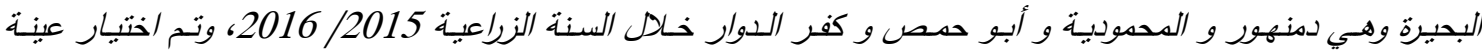

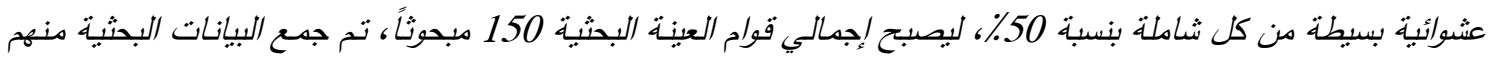

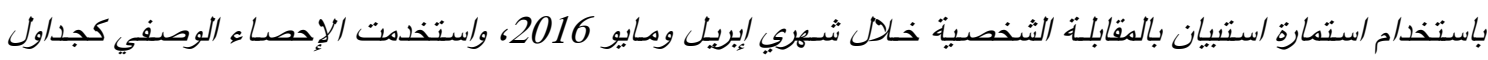
التوزيع التكراري العددي والنسبي، والمتوسط الحسابي، والانحراف الدعياري، ومعامل الإرتباط البسيط، والإحصاء الإستدلالي والئي كمعامل التحديد، ومعاملات كل من الإتباط المتعدد ، والإنحدار الجزئسي، والقياسي، إلسي جانب ندونج تحليل الارتباط الانحدارى العتعدد التدرجى الصاعد (Step-Wise) واختبار(t) كأدوات إحصائية لثرح وتفسير النتائج.

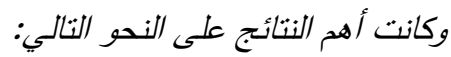
1- أعمار (سن) الدبحوثين: 55٪ من الزراع المبحوثين تتراوح أعمارهم بين (36 - 53) سنة، مقابل 40٪ من الدزارعات المبحوثات تشملهن نفس الفئة العدرية.

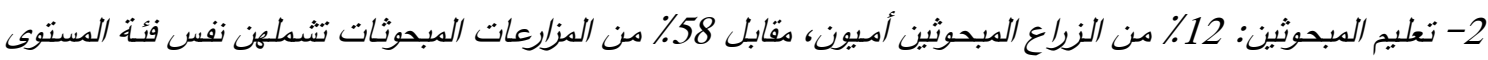

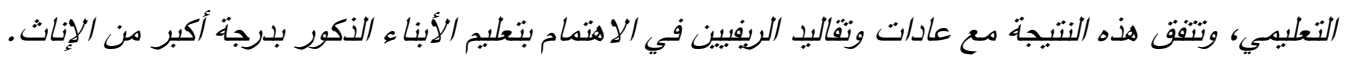

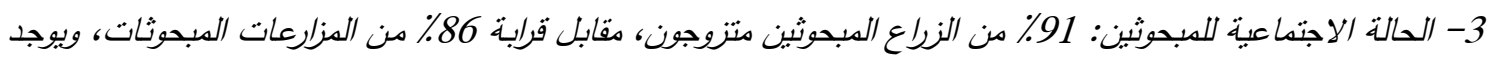
بين المزرعات المبحوثات مطلقات بنسبة 10٪، ولا يوجد من الزراع المبحوثين مطلقون. 4- الاتصال الدرجعي الدعرفي الزراعي: 62٪ من الزراع الدبحوثين، و62٪ من الدزارعات الدبحوثات تشملهم فئة الاتصال المرجعي المعرفي الزراعي المتوسط. 5- الدعم الإداري للددارس الحقلية: 99٪ من الزراع الدبحثثين، 100٪ من الدزارعات الدبحوثات أفادوا بارتفاع درجة الدعم الإداري للدداس الحقلية من قبل العسئولين عنها. 6- الاتجاه العـام للمبحوثين نحو الدـاس الحقلية: 83٪ من الـزراع المبحوثين، و66٪ من الدزارعات الدبحوثات ذوى اتجاهات إيجابية نحو الددارس الحقلية. 7- المشكلات التي تواجه المدارس الحقلية: أفاد المبحوثين بوجود العديد من المشكلات التي تواجههم أثناء المشاركة في

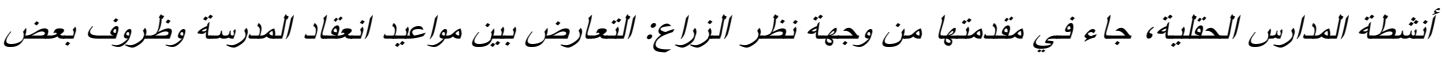
الزراع، وعدم وصول الدعم الإشادي في الميعاد الدناسب، وعدم الاهتمام بتجهيز مكان الددرسة بشكل مناسب. بينما

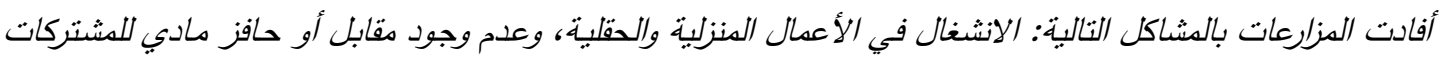
في الددرسة، ووجود مشاكل شخصية مع صاحب الحقل الدنفة به الددسة الحقلية. 


$$
\begin{aligned}
& \text { 8- sعنوية الفروق بين اتجاهات المبحوثين: لا توجد فروق ذات دلالة إحصائية بين مجهوعتي البحث من الزراع } \\
& \text { والمزارعات فيما بتعلق بطبيعة اتجا هاتهم نحو الددارس الحقلية. }
\end{aligned}
$$

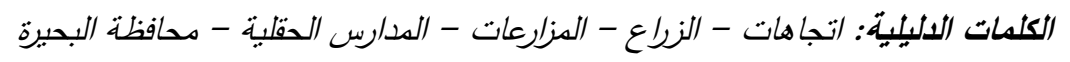

من جانب المزارعين تمنل عنصراً هاماً نحو التغير المنشود، كما تؤدي إلي نجاح الأشطة الإرشادية المختلفة،

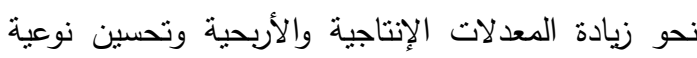
الحياة للسكان الريفيين من خلال إحداث تغيرات منشودة

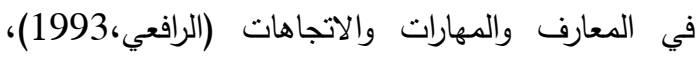
(الطنوبي، وعمران، 1997). وقد وجد أن من أسباب

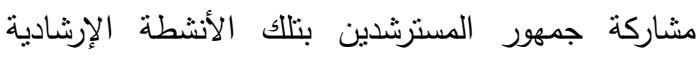
يرتبط بما تلبيه من حاجاتهم الملموسة ومصالحهم الفعلية

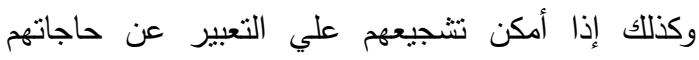
بوضوح، كما أنه من المرجح أن يشارك المزارعون إندان كانت الفوائد والمنافع الفعلية ترنبط ارتباطياً مبانشراً بمشاركتهم، وتحقيق فوائد ومنافع مادية، ومباشرة وفورية وخاصة لتلك الأنشطة المستحدثة منها (القرعلي نقلاً عن

$$
\text { قتنطة، وآخرون، 2000). }
$$

ولكي يحقق منهج الإرشاد بالمشاركة نتائجه المرجوة فإن عملية الاتصال التي تتم بين المزارعين والمرشدين ينبغي أن تتم بشكل بساعد علي تحقيق النعلم وتبادل

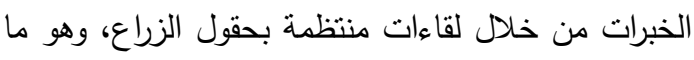

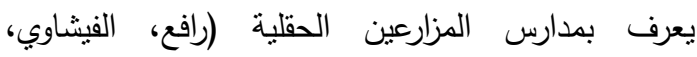
والكتانتي، 2003). وقد بدأت أنشطة المدارس الحقلية بمحافظة البحيرة في إطار التعاون بين إدارة الإرشاد

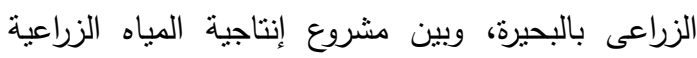

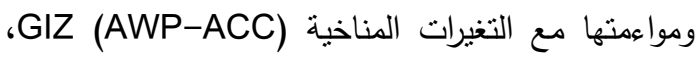
ومشروع تطوير الرى الحقلى IMP في الموسم الثنتوى 2015/2014، حيث نم افتتاح عدد 12 مدرسة حقلية

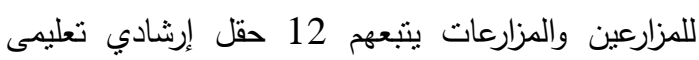
موزعة علي مستوي مراكز الححافظة، والمدرسة الحقلية عبارة مكان بسيط مظلل مفروش بالحصير مُعد على قطعة

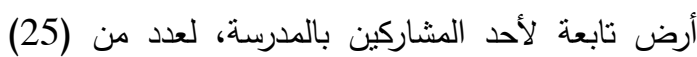

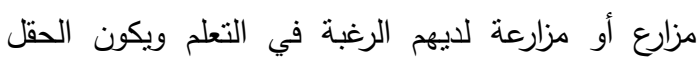
التعليمى بالقرب من مكان المدرسة، بحيث ليتمكن فيكن

\section{المقدمة والمشكلة البحثية}

يمثل القطاع الزراعي أحد القطاعات الحيوية في الاقتصاد المصري والذي يشهد في الآونة الأخيرة تغيرات عديدة، تلك التغيرات أثرت علي أسعار كل من مدخلات

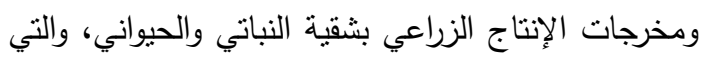
تتطلب تحقيق الوفرة والجودة في الإنتاج بإنباع أساليب

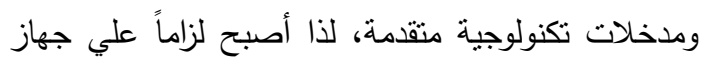
الإرشاد الزراعي إعادة النظر في آلية عمله وأسلوب أدائه بما يتتاسب مع متطلبات الحاضر والمستقبل. وحتي وقت قريب كان المرشد الزراعي يتبع أسلوباً

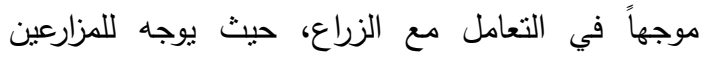
مجموعة من التوصيات بهذف زيادة إنتاجية المحصول،

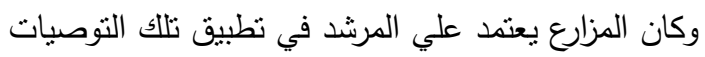

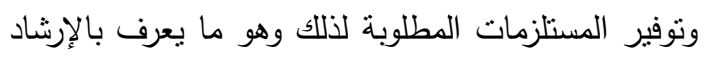
الموجه، إلا أن نتائج استخدام هذا الأسلوب أظهرت محدودية فعاليته في تشجيع المزارع علي تبني الأفكار

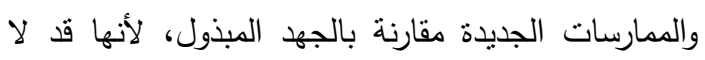

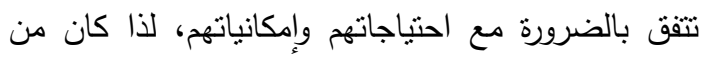
الضروري البحث عن مدخل جديد ملائم يستخدم آلية جديدة لتحقيق أهدافه، ألا وهو مدخل الإرشاد بالمشاركة،

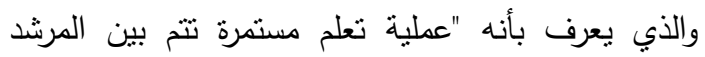

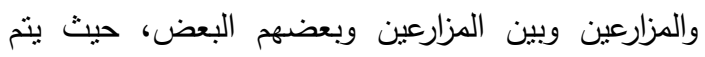

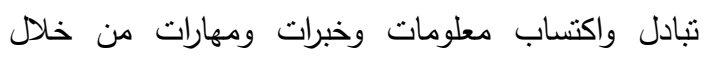
الحوار والمناقشة والمشاهدة بهدف زيادة وتحسين الإنتاج بما يؤدي إلي رفع مسنوي معيشة المزارعين (الإدارة المركزية للإرشاد الزراعي، ج2، 2001) ويعني هذا أن الإرشاد بالمشاركة يشجع المزارعين

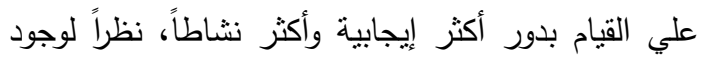
ملائمة وتوافق للأهداف المشتركة بين المزارعين والعاملين بجهاز الإرشاد الزراعي فلا شك أن نلك المشاركة الفعالة 
البحث ليكون بمثابة ضوء في هذا الججال البحثي بسترشد

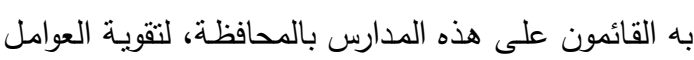
المساعدة على تكوين اتجاهات قوية لاى الزرع والمزارعات

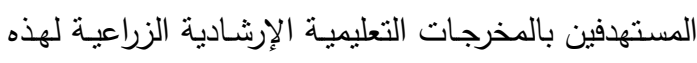

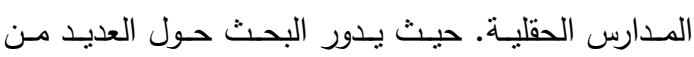
الأسئلة البحثية ومنها ما يلي: البهن

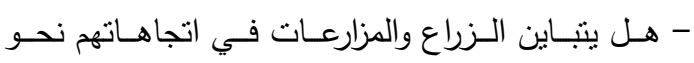
المدارس الحقلية؟

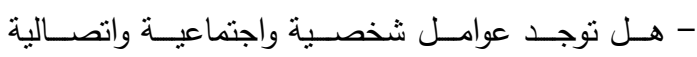
وإدارية... تؤثز على هذا الاتجاه؟ وما هي هذه العوامل؟

ومن المتوقع أن يساعد هذا البحث في الإجابة على لـى

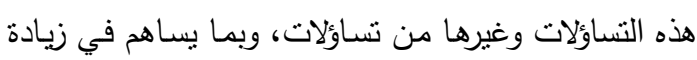

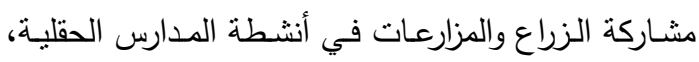
والتتبؤ بسلوكهم في ضوء هذه العوامل ومن خلال تدعيمها لتقويـة اتجاهـات المستقفيدين مـن هذه المـارس، وبالتـالي تعظيم الاستفادة منها. أهداف البحث الثم:

بستهدف هذا البحث تحقيق الأهداف البحثية التالية:

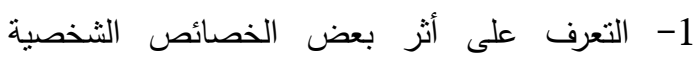

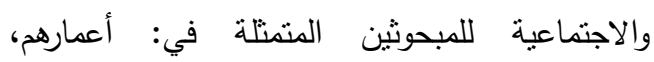
ومستوياتهم التعليمية، وحالتهم الاجتماعية، واتصالهم الهيخ

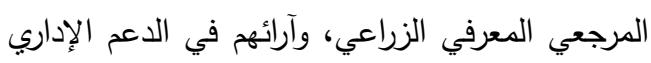

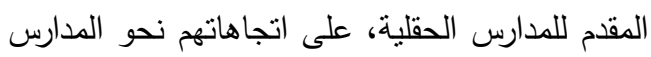
الحقلية بمنطقة البحث. 2- التعرف على العلاقة بين اتجاهات المبحوثين نحو

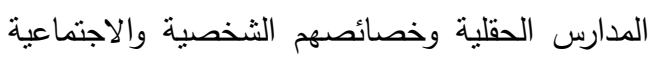
والاتصالية والإدارية الدذكورة في الهدف الأول أعلاه.

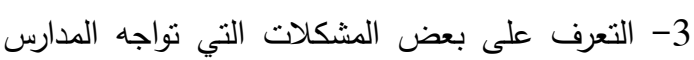
الحقلية من وجهة نظر المبحوثين. فروض البحث لتحقيق الهدف البحثي الثناني، تم صباغة الفروض النئ

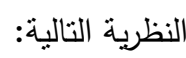
1- نوجـــــــروق معنويـة بـين الخصــائص الشخصـية

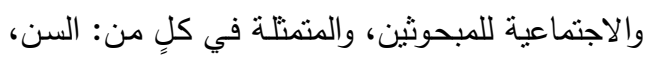

المشاركون من تجريب مختلف الممارسات الزراعية التىى يتم تتاولها داخل الدرسة الحقلية ويتم ذلك النشاط بشكل

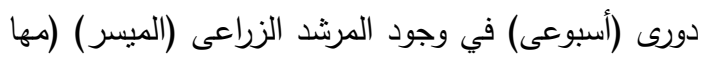
حرحش وعبد الحليم، 2016). وتتعدد أسباب مشاركة الزراع بالمدارس الحقلية فهي كما وجد (القرعلي، 2000) تتمثل في الاستفادة بالخدمات

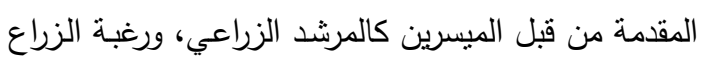

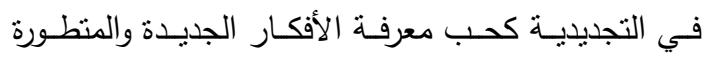
والاستفادة بما تطرحه من توصيات. وتشير أدبيات وعلوم الإرشـاد الزراعي أن هناك العديد من العوامل التي تؤئثر

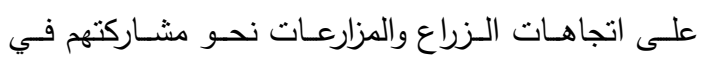
الأنشطة الإرشادية الزراعية. ولما كانت المدارس الحقلية أحد الطرق المستحدثة في التعليم الإرشادي الزراعي، فإنه الرنه

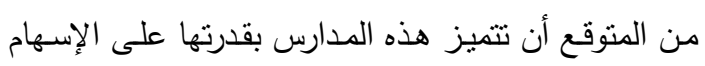

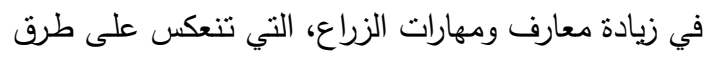

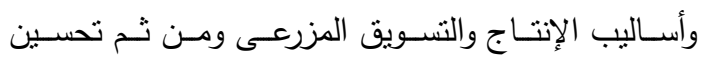

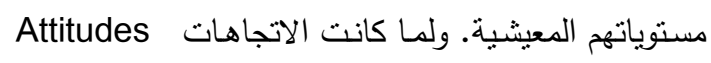

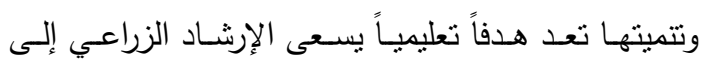

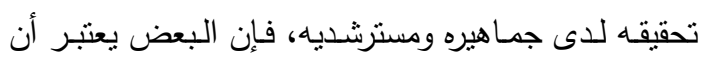

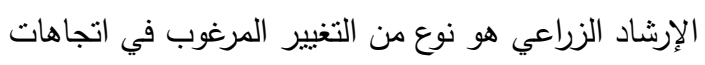
الزراع نحو التغيير ذاته (Maunder، 1973). ويعتبر تغيير اتجاهات الزراعنحو المدارس الحقلية،

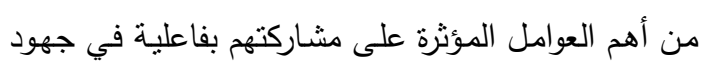

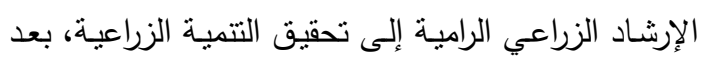

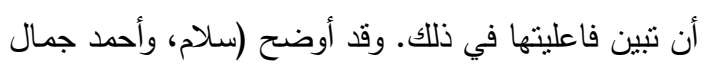

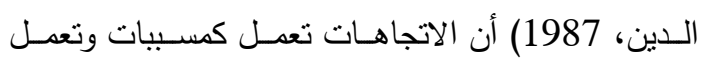

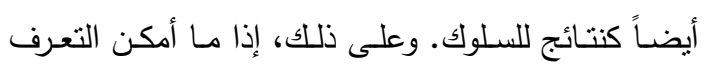

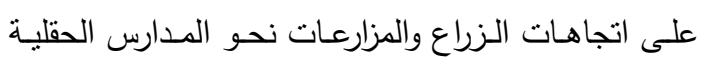

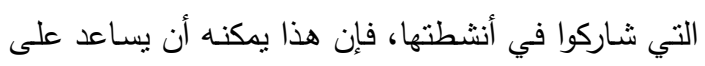

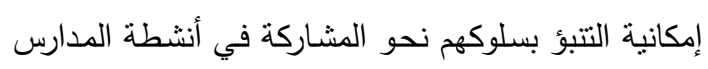
الحقلية. وفى ضوء ندرة البحوث التي أجريت على اتجاهات الزراع والمزارعات نحو الهدارس الحقلية والعوامل المؤثرة

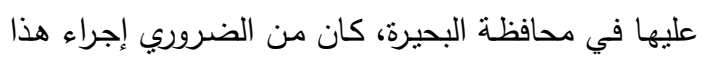


غالبيـة حكومـات العـالم اعتمدت بشكلٍ كبير على هذه الصفات في زيادة إنتاجها من المحاصيل الزراعية المختلفة كئل من خلال نبنى المزارعين للأساليب التكنولوجية الحديثة. ولما كانت مدارس المزارعين الحقلية تعتبر أسلوباً

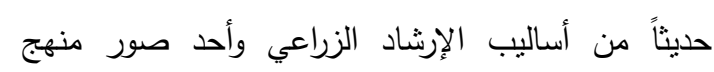

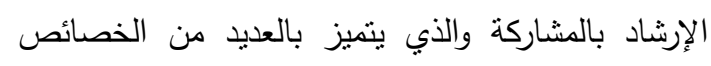

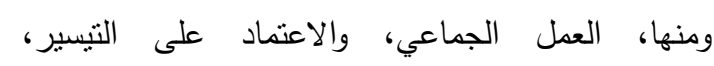

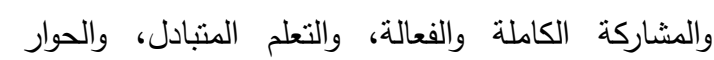

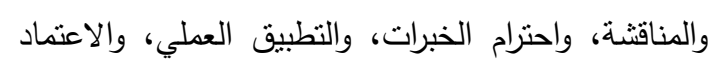

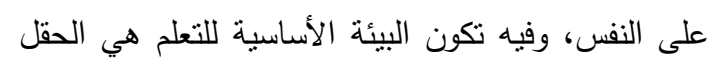
الذي يتم فيه تتفيذ كافة الأنشطة التعليمية (الإدارة المركزية النية النية النية

$$
\text { للإرشاد الزراعي، ج2، 2001). }
$$

ولما كانت الملاحظات الميدانية نشير إلى تباين سلوك

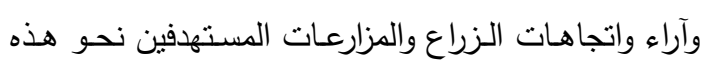
المدارس الحقلية، وبالتالي فقد ظهرت الحاجة إلي إجراء هذا البحث للتعرف على بعض العوامل التي قد يكون لها لهات التهاء

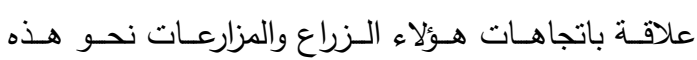
المدارس.

\section{المنهج والطريقة البحثية}

\section{المتغيرات البحثية وتعريفاتها الإجرائية:}

1- عمر المبحوث (السن): ويقصد بـه عدد سنوات عمر الجريه

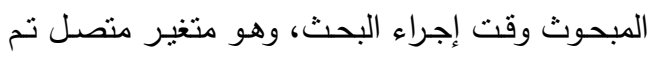

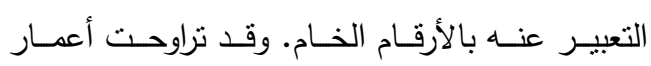
المبحـوثين بـين (18- 72 سـنة)، وعلى ذلـ بلك أمكن تقسيم المبحوثين من خلالها إلى ثـلاث فئات عمريـة (سنة) هي: الفئة الأولى من (18- 35 سنة)، والفئة الثنانية من (36 - 53 سنة)، والفئة الثالثة (من 54 سنة فأكثر). 2- المستوى التعليمسي: هـو السستوى التعليهـي النظـامي

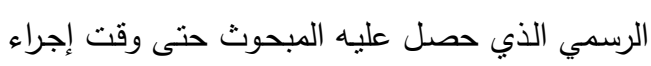
البحث، وهو متغير منصل تم التعبير عنه بقيم رقمية

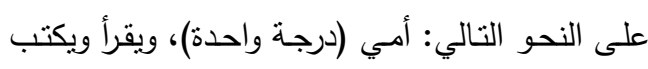

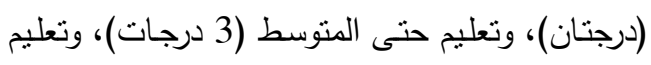

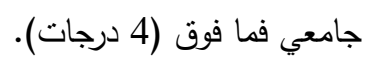

والمستوى النعليمي، والحالـة الاجتماعيـة، والاتصـال

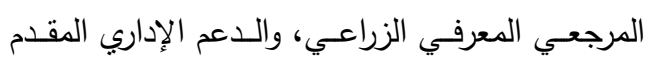

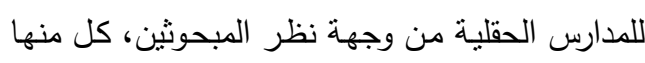
منفرداً على حده.

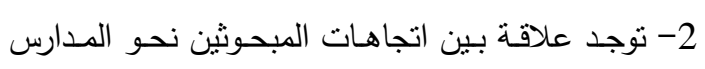
الحقلية (كمتغير تابع)، وكلٍ من المتغيرات المستقلة

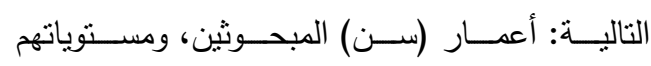

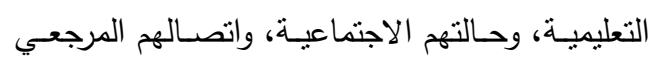

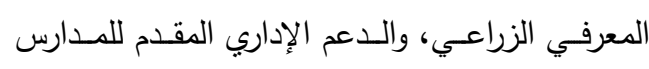
الحقلية، كلٍ منها منفرداً على حده.

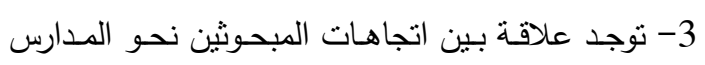

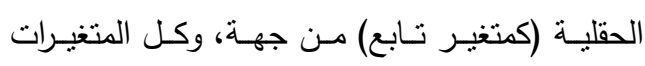

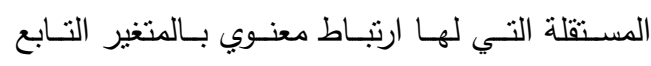
مجتمعة من جهة أخرى.

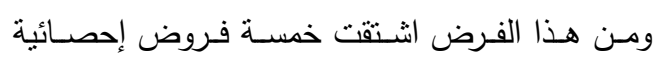

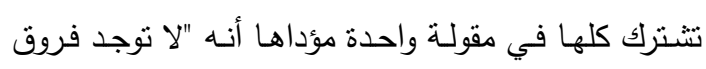

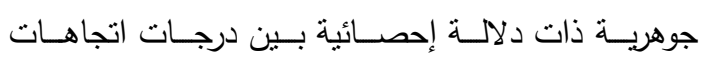

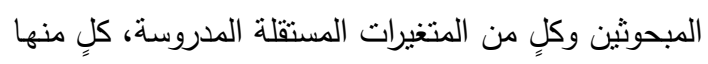
منفرداً على حده". الاستعراض المرجعي

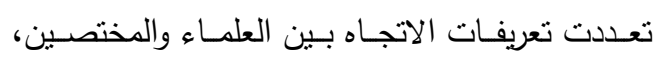

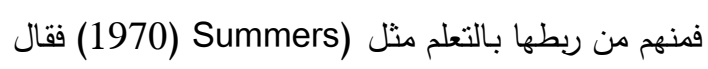
أن الاتجاهات أمر مكتسب بتنكون لدى الثخص من من خلال

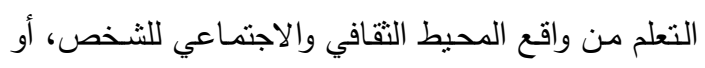
هو ميـل الفـرد لثقيـيم موضـوع أو رمـز بطريقـة معينـة. ويعرف Krech \& Crutechfeld (1948) الاتجاهات بأنها منظم مستمر للعمليات الواقعية والعاطفية والإدراكية والمعرفية المتعلقة بجوانب معينة من عالم الفرد.

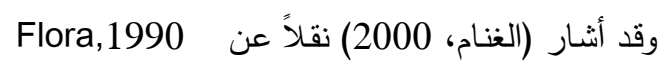

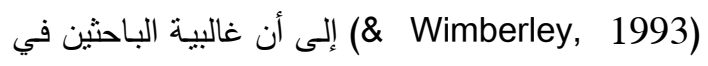

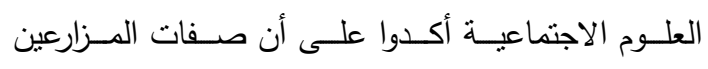

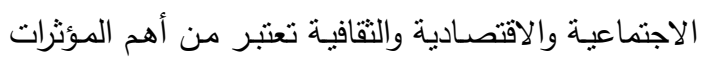
الدافعة للتغيير وتتمية المناطق الريفية وتغيير هيكل البناء

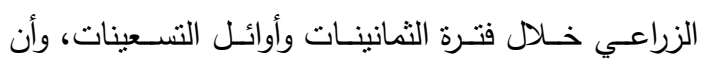


وتحديد موقـع ومكـان مناسـب وغير بعيد، واسـتقبال

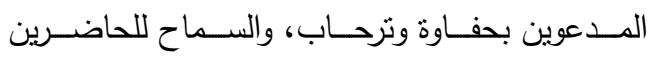
بالتحدث بحرية وعرض مشكلاتهم، وتوافر متخصصين

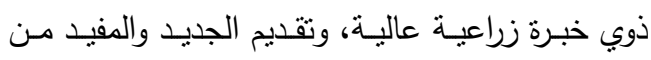

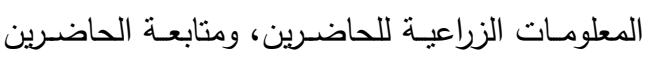

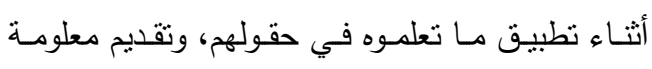

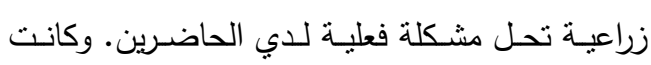
الاستجابة المطلوبة هي (يحدث دائهاً، ويحدث أحياناً،

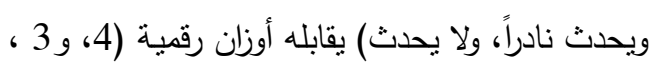

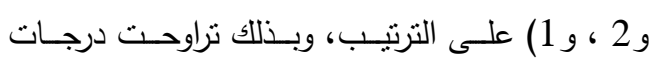
القياس النظري بين (10 - 40 درجة)، وعلى ذلت ذلك تم تقسيم المبحوثين من خلالها إلى ثلاث فئات هي: الفئة

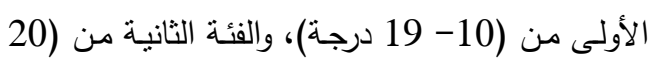

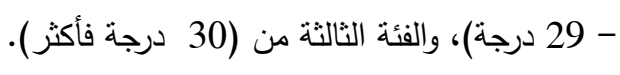

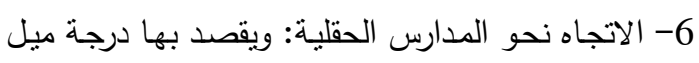

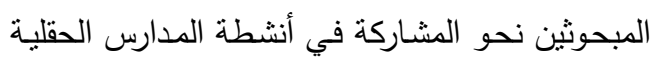
التي ينت تتفيذها في حقولهم ويشتركون في أنشطتها،

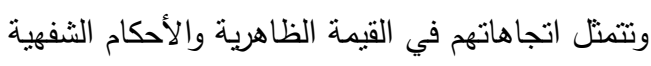
التي يعبرون بها نحو المدارس الحقليـة، وذلك من فئن

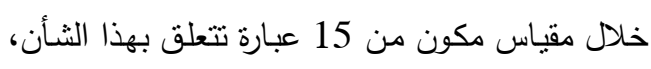

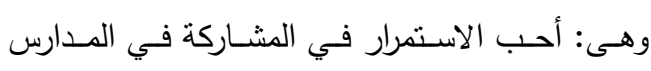

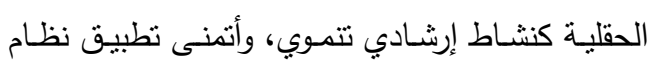

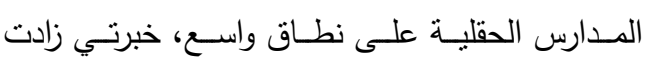

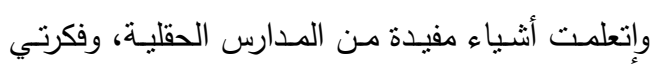

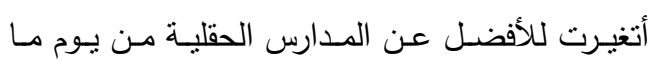
حضرت فيها، والمدارس الحقلية مهمة لنشر الأفكار الزراعيـة الجديدة، والمدارس الحقلية بتقوم بدور كبير

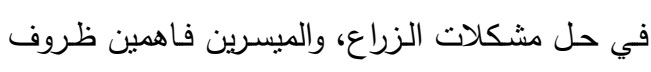

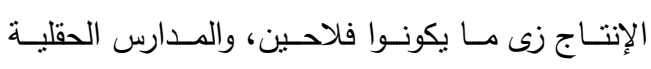

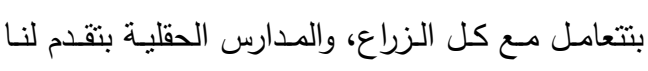
معلومات نظرية دون المساعدة في النطبيق، وإمكانيات

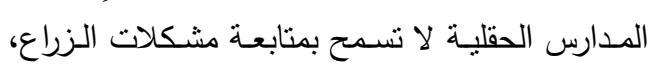
والأنشـطة الإرثــادية الزراعيـة في المـدارس الحقليـة

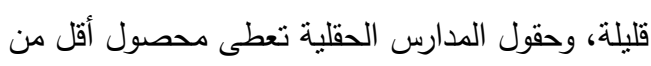

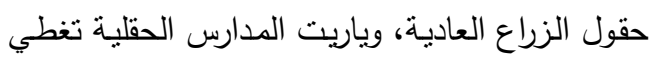

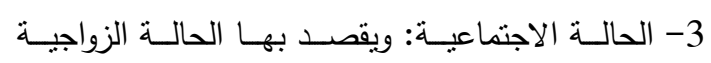
للمبحوث وقت إجراء البحث، وهو متغير منقطع، تم

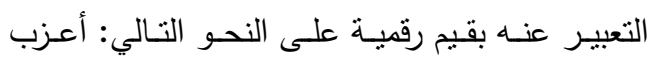

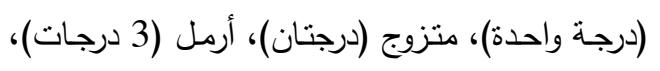
مطلق (4درجات). 4- الاتصال المرجعي المعرفي الزراعي: ويقصد به درجة

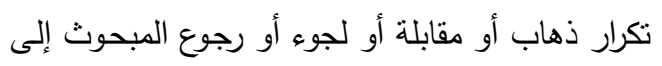

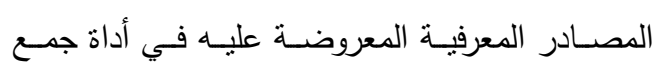

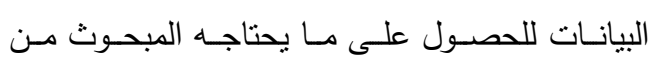
معارف أو مهارات أو خبرات أثناء المراحل المختلفة

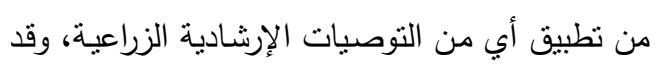

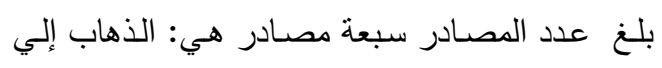

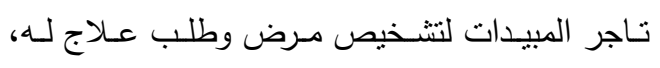

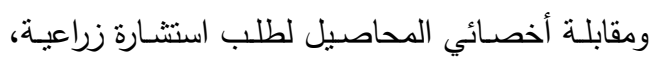

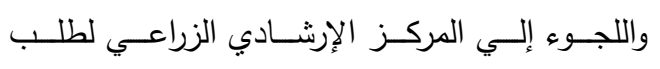

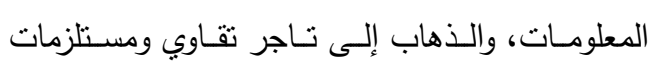

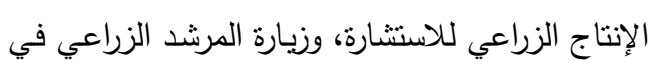

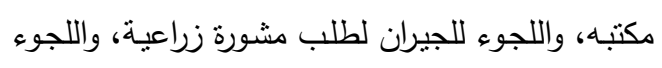

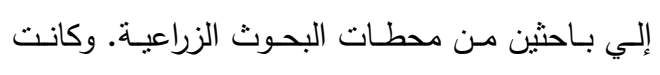

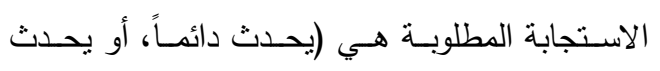

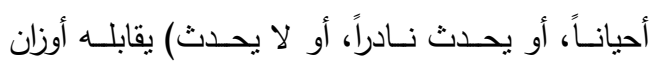

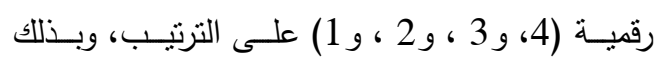

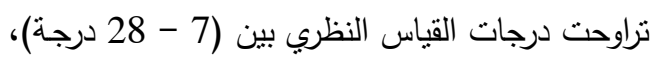
وعلى ذلك تم تقسيم المبحوثين من خلالها إلى ثنلاث فئسات هـي: اتصـال قليـل (7- 13 درجـة)، اتصــال

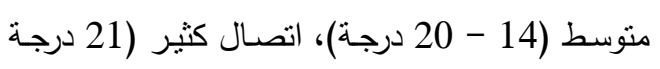
فأكثر ). 5- الدعم الإداري للمدارس الحقلية: ويقصد بهـا تقديرات

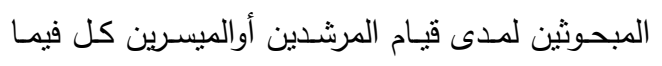

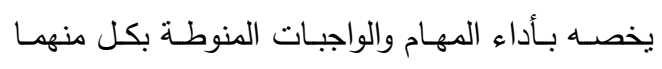

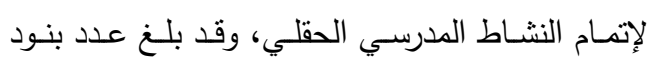

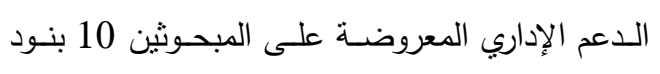

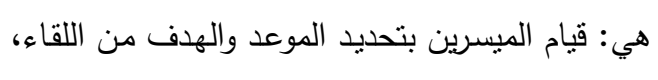

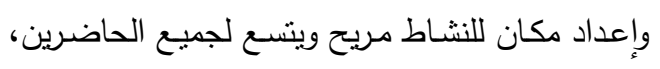

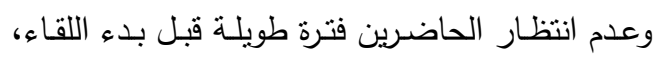


الإرتباط المتعدد ، والإنحدار الجزئي، والقياسي، إلي جانب

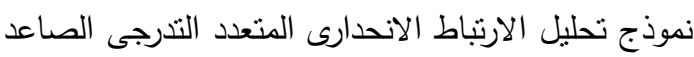
واختبار (t) كأدوات إحصائية لثرح (Step- Wise)

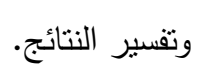

\section{عرض النتائج البحثية ومناقشتها}

أولاً: الخصــائص الثخصـية والاجتماعيـة والاتصــالية

والإدارية:

1- أعمار المبحوثين (السن): ترجع أهمية معرفة أعمار

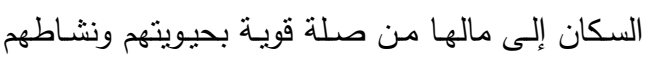

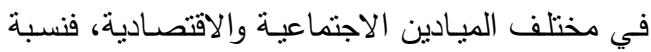

السكان في سن العمل تحدد القوة البشرية العاملة أي

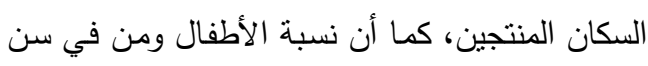
الثيخوخة تحدد نسبة العجزة والمعـولين أي السكان العنان

$$
\text { غير المنتجين. (عتمان، 1989). }
$$

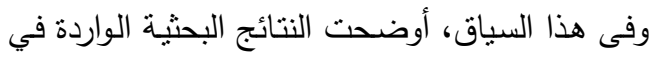
جـول (1) أن غالبيـة المبحـوثين مـن الـزراع المبحــثين ونسبتهم 55\% تثملهم الفئة العمرية من (18 - 53) سنة، مقابل 40٪ من المزارعات المبحوثات تثملهن نفس الفئة الفئة

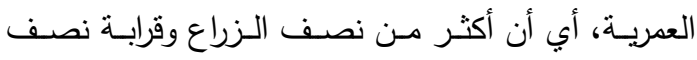

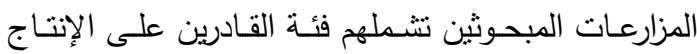

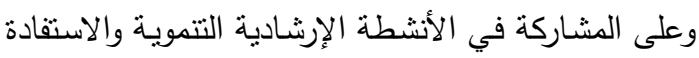
منها، وقد يؤثر ذلك على طبيعة اتجاهاتهم نحو أنشطة الأنة

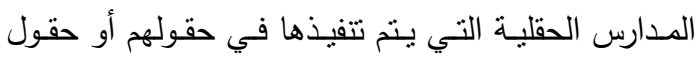
أقرانهم وجيرانهم.

وللتحقق من عدم وجود فروق جوهرية بين متوسطي

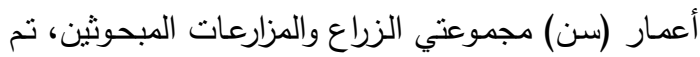
الإسـتعانة باختبـار (t-Test) كـأداة إحصـائية لاختبـار

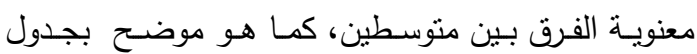

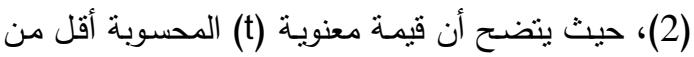
0.05 وهذا معناه وجود فروق معنوية بين منوسطي أعمار

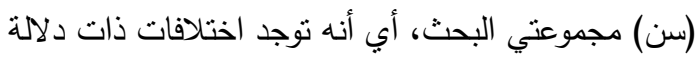

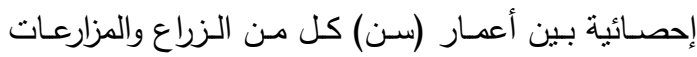

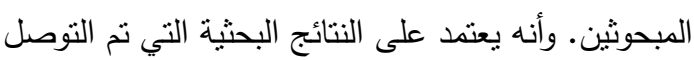

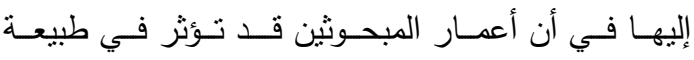

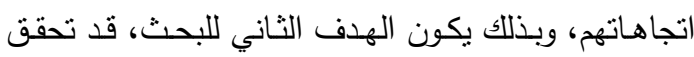
جزئياً.
كل ما يتعلق بالريفيات والمنزل الريفي، ومن الأفضل

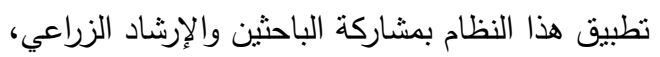

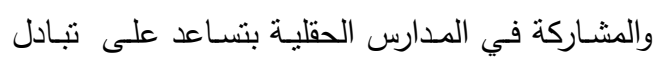
الخبرات والأفكار الجديدة. حيث يقوم المبحوث بتحديد موقفه من كل عبارة (موافق، وموافق لحد ما، وغير موافق) يقابلهـا أوزان رقميـة (3، و 2 2 ، و 1) للعبـارات

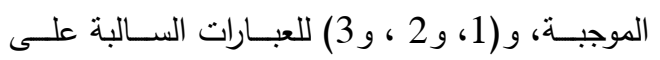
الترتيب. وبذلك تراوحت الدرجات النظرية للمقياس بين

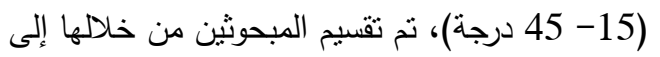

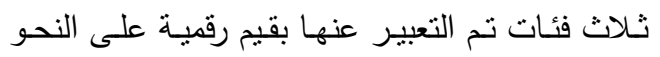

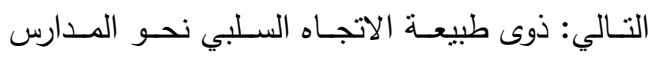
الحقلية مـن (15- 24 درجـة)، وذوى طبيعـة الاتجـاه المحايد من (25- 34 درجـة)، وذوى طبيعـة الاتجـاه الإيجابي من (35 درجة فأكثر).

الثاملة والعينة البحثية: للبحث شاملتان نظريتان، تمثلت الثـاملة الأولى في جميـع الـزراع وعددهم 200 مـزارع حضروا أنشطة المدارس الحقلية في 8 مدارس مخصصية لهم بمراكز دمنهور وأبو حمص وكفر الدوار بمحافظـة الثنة

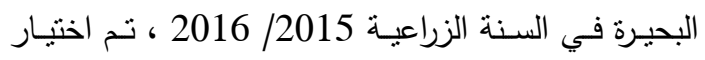

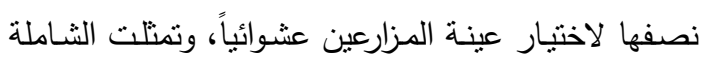
الثانية في جميع المزارعات وعددهن 100 مزارعة حضرن أننطة المدارس الحقلية وعددها 4 مدارس مخصصة لهن لهن بمراكز المحمودية وأبوحص وكفر الدوار بمحافظة البحيرة

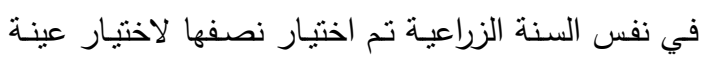

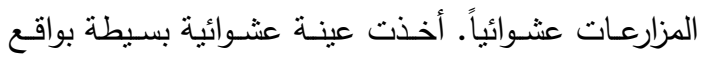

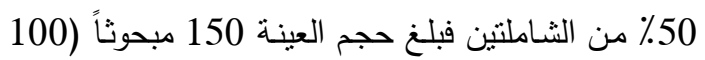
مزارع + 50 من مزارعة). أدوات جـــع البيانـات: استخدم استبيان موحداً للعينتين

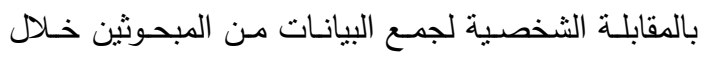

$$
\text { شهري أبريل ومايو } 2016 .
$$

الأساليب الإحصائية: استخدمت الإحصاء الوصني

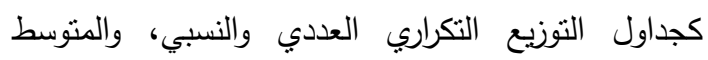
الحسابي، والانحراف المعياري، ومعامل الإرتباط البسيط، والإحصاء الإستدلالي كمعامل التحديد، ومعاملات كل من الإنحان 
وفى هذا الصـدد، تشـير النتـائج البحثيـة الـواردة في جدول (3) إلى أن 12\% فقط من الزراع المبحوثين أميون

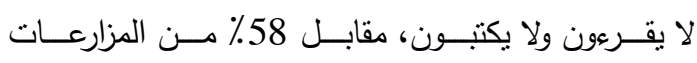
المبحوثات اللائي تشملهن نفس فئة المستوى التعليمي، وقد

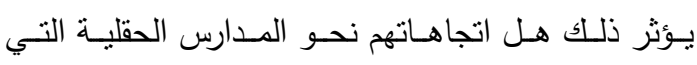
يشاركون في أنشطتها.
2- المستوى التعليمي: من المسلم بـه أن التعليم يعتبر من أكثر المحكات التي تحرص عليها المجتمعات المثقدمة والمتخلفـة على السـواء، حيـث يعمل على الاسـتنمار فيها نظراً لارتفاع عوائدها مقارنة بغيرها. فالتعليم يؤثز في سـلوك الأفـراد واتجاهـاتهم ونحـو كثيـر مـن القيم

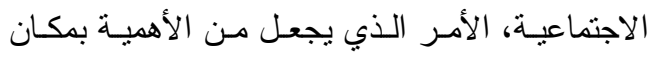

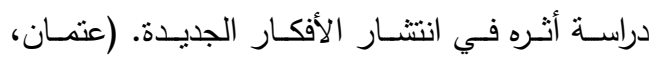

.). 1989

جدول (1): التوزيع العددي والنسبي لمتغير أعمار (سن) المبحوثين

\begin{tabular}{|c|c|c|c|c|c|}
\hline \multicolumn{3}{|c|}{ عينة المزارعات } & \multicolumn{3}{|r|}{ عينة الزراع } \\
\hline$\%$ & عدد & فئات العمر ( السن ) & $\%$ & عدد ع & فئات العمر ( السن ) \\
\hline 40 & 20 & - ( 18 - 35 ) سنة & 9 & 9 & - ( 18 - 35 ) سنة \\
\hline 40 & 20 & - ( 36 - 53 ) سنة & 55 & 55 & - ( 36 - 53 ) سنة \\
\hline 20 & 10 & - ( 54 سـنة فأكثز) & 36 & 36 & - ( 54 سـنة فأكثر) \\
\hline 100 & 50 & المجمــــوع & 100 & 100 & المجمــــوع \\
\hline \multicolumn{2}{|c|}{39.94} & المتوسط الحسابي & \multicolumn{2}{|c|}{48.82} & المتوسط الحسابي \\
\hline \multicolumn{2}{|c|}{12.55} & الانحراف المعياري & \multicolumn{2}{|c|}{10.12} & الانحراف المعياري \\
\hline
\end{tabular}

جدول (2): اختبار (t) لمعنوية الفرق بين متوسط أعمار (سن) المبحوثين

\begin{tabular}{|c|c|c|c|}
\hline t قيمة معنوية & درجات الحرية & قيمة t & اسم المتغير \\
\hline 0.01 & 148 & 4.669 & \multirow{2}{*}{ لعمر (السن) } \\
\hline 0.01 & 81.68 & 4.346 & \\
\hline
\end{tabular}

جدول (3): التوزيع العددي والنسبي لمتغير المستوى التعليمي للمبحوثين

\begin{tabular}{|c|c|c|c|c|c|}
\hline \multicolumn{3}{|r|}{ عينة المزارعات } & \multicolumn{3}{|c|}{ عينة الزراع } \\
\hline$\%$ & عدد & درجات المستوى التعليمي & $\%$ & 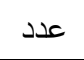 & درجات المستوى التعليمي \\
\hline 58 & 29 & 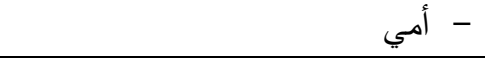 & 12 & 12 & 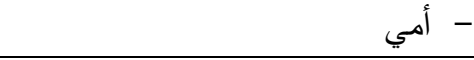 \\
\hline 16 & 8 & - يقرأ ويكتب & 47 & 47 & - يقرأ ويكتب \\
\hline 26 & 13 & - تعليم حتى المتوسط & 31 & 31 & - تعليم حتى المتوسط \\
\hline صفر & صفر & - تعليم جامعي فما فوق & 10 & 10 & - تعليم جامعي فما فوق \\
\hline 100 & 50 & المجمــــوع & 100 & 100 & المجمـــــوع \\
\hline \multicolumn{2}{|c|}{1.68} & المتوسط الحسابي & \multicolumn{2}{|c|}{2.39} & المتوسط الحسابي \\
\hline \multicolumn{2}{|c|}{0.88} & الانحراف المعياري & \multicolumn{2}{|c|}{0.83} & الانحراف المعياري \\
\hline
\end{tabular}


3- الحالة الاجتماعية: تبين النتائج الواردة في جدول (5)

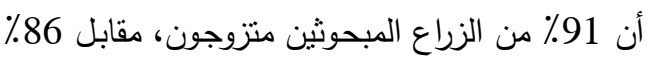

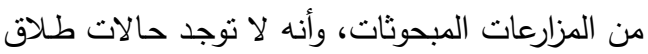
بين الزراع المبحوثين، مقابـل 10٪ مـن المزارعـات المبحوثات، وقد يؤثر ذلك على ما يتاح للمبحوثين من الترن

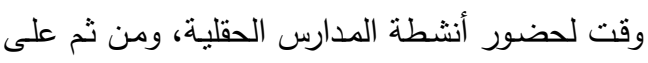

$$
\text { اتجاهاتهم نحوها. }
$$

وللتحقق من عدم وجود فروق جوهرية بين منوسطي درجات الحالـة الاجتماعيـة لمجموعتي الزراع والمزارعات المبحوثين، نم الإستعانة باختبار (t-Test) كأداة إحصائية

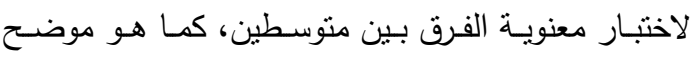

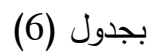

وللتحقق من عدم وجود فروق جوهريـة بين متوسطي درجات المستوى التعليمي لهمهوعتي الزراع والمزارعات المبحوثين، نم الإستعانة باختبار (t-Test) كأداة إحصائية لاختبار معنويـة الفرق بين منوسطين، كما هو موضـح بجدول (4) ، حيث تثير النتائج البحثية أن قيمة معنوية

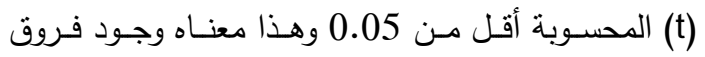
معنوية بين متوسطي درجات المستوى التعليمي لمجموعتي البحث، أي أنـه توجد اختلافات ذات دلالة إحصائية بين درجـات المستـوى التعليمسي لكلٍٍ مـن الـزراع والمزارعـات

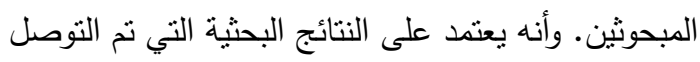

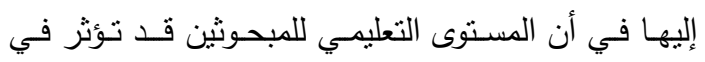

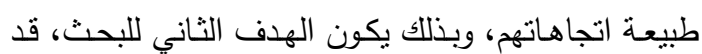

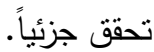
جدول (4): اختبار (t) لمعنوية الفرق بين متوسطي درجات المستوى التعليمي لمجموعتي المبحوثين

\begin{tabular}{|c|c|c|c|}
\hline قيمة معنوية t & درجات الحرية & قيمة t & اسم المتغير \\
\hline 0.01 & 148 & 4.874 & \\
\hline 0.01 & 94.08 & 4.798 & مشئوs \\
\hline
\end{tabular}

جدول (5): التوزيع العددي والنسبي لمتغير الحالة الاجتماعية للمبحوثين

\begin{tabular}{|c|c|c|c|c|c|}
\hline \multicolumn{3}{|r|}{ عبنة المزارعات } & \multicolumn{3}{|r|}{ عينة الزراع } \\
\hline$\%$ & عدد & فئات الحالة الاجتماعية & $\%$ & عدد & فئات الحالة الاجتماعية \\
\hline 2 & 1 & - أعزب - أع & 7 & 7 & - - أعزب \\
\hline 86 & 43 & - متزوج - متز & 91 & 91 & - - متزوج \\
\hline 2 & 1 & 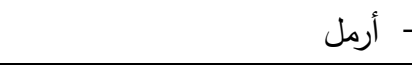 & 2 & 2 & - أرمل \\
\hline 10 & 5 & - مطلق - - مط & صفر & صفر & - مطلق - مط \\
\hline 100 & 50 & ل المجمــــوع & 100 & 100 & المجمـــــوع \\
\hline \multicolumn{2}{|c|}{2.20} & المتوسط الحسابي & \multicolumn{2}{|c|}{1.97} & المتوسط الحسابي \\
\hline \multicolumn{2}{|c|}{0.64} & الانحراف المعياري & \multicolumn{2}{|c|}{0.39} & الانحراف المعياري \\
\hline
\end{tabular}

جدول (6): اختبار (t) لمعنوية الفرق بين متوسطي درجات الحالة الاجتماعية لمجموعتي المبحوثين

\begin{tabular}{|c|c|c|c|}
\hline قيمة معنوية t & درجات الحرية & قيمة t & اسم المتغير \\
\hline 0.007 & 148 & $2.734-$ & $\therefore \quad 10=1$ \\
\hline 0.022 & 67.61 & $2.339-$ & الحالح الا جلماعية \\
\hline
\end{tabular}


الاتصـال المرجعي المعرفي الزراعي الكثير ، مقابل

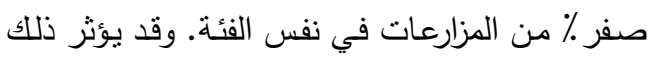

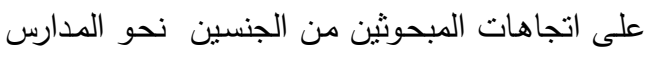

الحقلية.

وباستعراض استجابات الزراع المبحوثين وفقاً لنكرارات

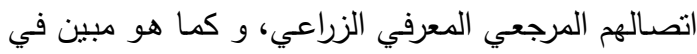
جدول (8) يتضح أن 39٪ منهم يذهبون دائماً إلى تجار

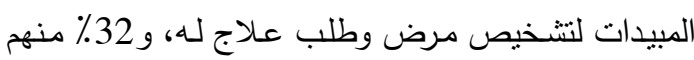

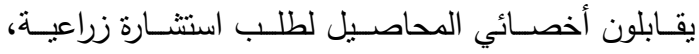

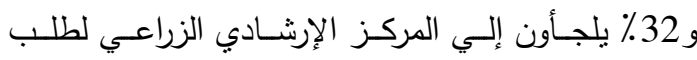

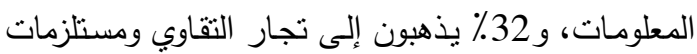

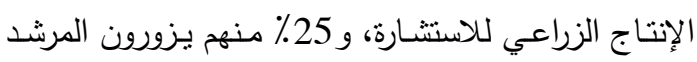

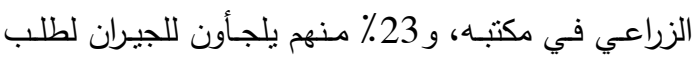

مشورة زراعية.
ومن جدول (6)، يتضح أن قيمة معنوية (t) المحسوبة

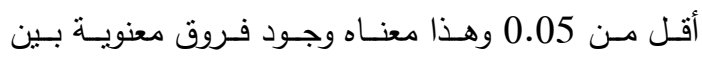
متوسطي درجات الحالة الاجتماعية لهجموعني البحث، أي وندان

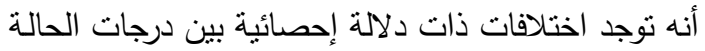

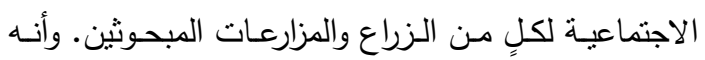

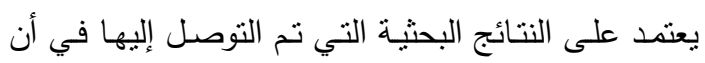

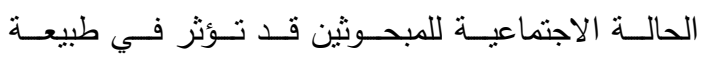

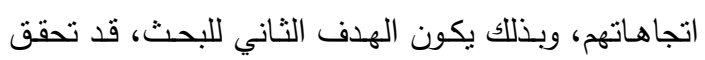
جزئياً. 4- الاتصـال المرجعي المعرفي الزراعي: نتـير النتائج

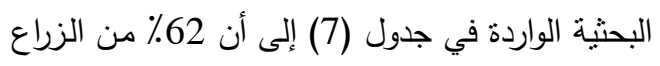

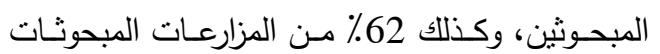

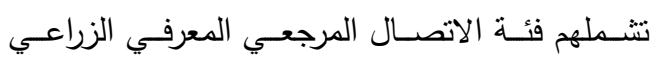

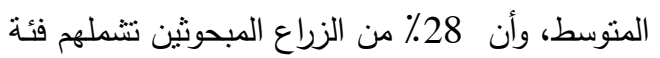

جدول (7): التوزيع العددي والنسبي لمتغير المصادر المعرفية المرجعية للمبحوثين

\begin{tabular}{|c|c|c|c|c|c|}
\hline \multicolumn{3}{|r|}{ عينة المزارعات } & \multicolumn{3}{|r|}{ 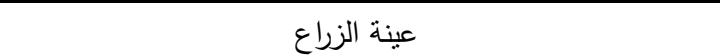 } \\
\hline$\%$ & عدد & فئات الاتصال المرجعي المعرفي الزراعي & $\%$ & عدد & فئات الاتصال المرجعي المعرفي الزراعي \\
\hline 38 & 19 & - قليـل ( 7 - 13 ) درجة & 10 & 10 & - قليـل ( 7 - \\
\hline 62 & 31 & - متوسط ( 14 - 20 ) درجة & 62 & 62 & - متوسط ( 14 - 20 ) درجة \\
\hline صفر & صفر & - كثيــر ( 21 درجة فأكثر ) & 28 & 28 & - كثيــر ( 21 درجة فأكثر ) \\
\hline 100 & 50 & المجمــــوع & 100 & 100 & المجمــــوع \\
\hline \multicolumn{2}{|c|}{14.48} & المتوسط الحسابي & \multicolumn{2}{|c|}{18.6} & المتوسط الحسابي \\
\hline \multicolumn{2}{|c|}{4.15} & الانحراف المعباري & \multicolumn{2}{|c|}{3.74} & الانحراف المعياري \\
\hline
\end{tabular}

المصدر : استبيان البحث، 2016، لعدد (100 مزارع مبحوث، 50 مبحوثة).

جدول (8): التوزيع التكراري والنسبي لمتغير الاتصال المرجعي المعرفي الزراعي للزراع للمبحوثين

\begin{tabular}{|c|c|c|c|c|c|c|c|c|c|}
\hline \multicolumn{8}{|c|}{ تكرارات استجابات المبحوثين } & \multirow{3}{*}{ الاتصال المرجعي المعرفي الزراعي } & \multirow{3}{*}{ r } \\
\hline \multicolumn{2}{|c|}{ لا يحدث } & \multicolumn{2}{|c|}{ بحدث نادراً } & \multicolumn{2}{|c|}{ يحدث أحياناً } & \multicolumn{2}{|c|}{ يحدث دائماً } & & \\
\hline$\%$ & ت & $\%$ & $ت$ & $\%$ & 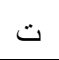 & $\%$ & $ت$ & & \\
\hline 5 & 5 & 23 & 23 & 33 & 33 & 39 & 39 & الذهاب إلي تاجر المبيدات لنتخيص مرض وطلب علاج له. & 1 \\
\hline 25 & 25 & 12 & 12 & 31 & 31 & 32 & 32 & مقابلة أخصائي المحاصيل لطلب استشارة زراعية. & 2 \\
\hline 29 & 29 & 14 & 14 & 25 & 25 & 32 & 32 & اللجوء إلي المركز الإرشادي الزراعي لطلب المعلومات. & 3 \\
\hline 28 & 28 & 23 & 23 & 17 & 17 & 32 & 32 & الذهاب إلى تاجر نقاوي ومستلزمات الإنتاج الزراعي للاستشارة. & 4 \\
\hline 31 & 31 & 18 & 18 & 26 & 26 & 25 & 25 & زيارة المرشد الزراعي في مكتبه . & 5 \\
\hline 5 & 5 & 32 & 32 & 40 & 40 & 23 & 23 & اللجوء للجيران لطلب مشورة زراعية. & 6 \\
\hline 48 & 48 & 20 & 20 & 25 & 25 & 7 & 7 & اللجوء إلي باحثين من محطات البحوث الزراعية. & 7 \\
\hline
\end{tabular}

المصدر : استيان البحث، 2016، لعدد (100 مزارع مبحوث). 


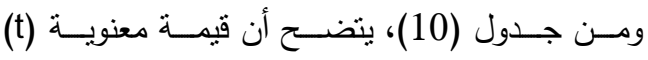
المحسوبة أقل من 0.05 وهذا معناه وجود فروق معنوية لئة بين منوسطي درجات الاتصال المرجعي المعرفي الزراعي

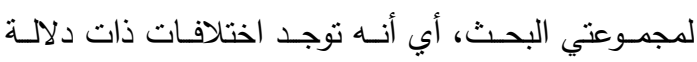
إحصائية بين درجات الاتصـال المرجعي المعرفي الزراعي لئي

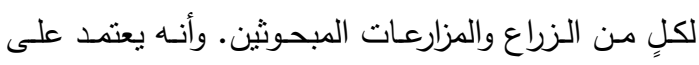

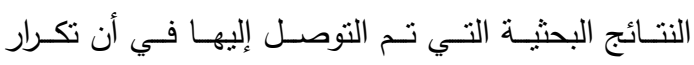
الاتصال بالمصادر المرجعية المعرفية الزراعية للمبحوثين

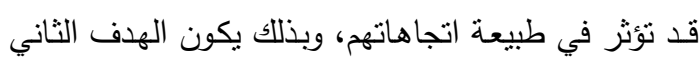
للبحث، قد تحقق جزئياً.

5- الدعم الإداري للمدارس الحقلية: توضح النتائج البحثية

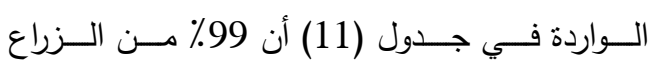
المبحوثين، و 100٪ من المزارعات المبحوثات، أفادوا بارتفاع درجـة الدعم الإداري المقدم للمدارس الحقلية

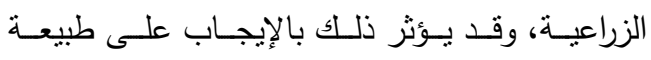
اتجاهاتهم نحو المدارس الحقلية التي يحضرونها.
وبمقارنة استجابات المزارعات المبحوثات وفقاً لتكرارات اتصالهن المرجعي المعرفي، وكما هو مبين في جدول (90) يتضـح أن60\% من المزارعات المبحوثات يلجأن للجيران

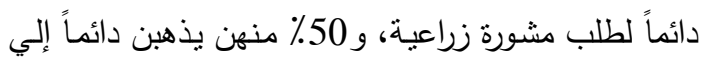
تاجر المبيدات لتتخيص مرض وطلب علاج له، و 40٪ منهن يذهبن دائمساً إلى تـاجر نقاوي ومستلزمات الإنتاج الزراعـي للاستشــارة، و 26٪ مـنهن تلجـأن إلـي المركـز

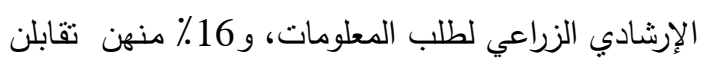

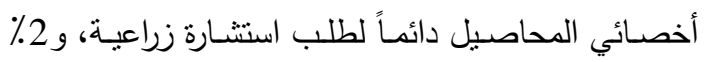
منهن يقمن بزيارة المرشد الزراعي في مكتبه، ولا نلجأ أي لئي منهن إلي باحثين من محطات البحوث الزراعية. وللتحقق من عدم وجود فروق جوهريـة بين متوسطي

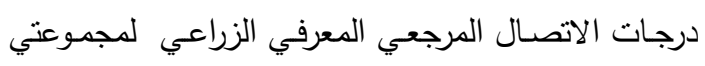

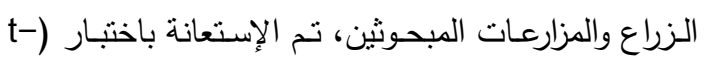
(Test منوسطين، كما هو موضح بجدول (10). جدول (9): التوزيع التكراري والنسبي لمتغير الاتصال المرجعي المعرفي الزراعي للمزارعات المبحوثات

\begin{tabular}{|c|c|c|c|c|c|c|c|c|c|}
\hline \multicolumn{8}{|c|}{ تكرارات استجابات المبحوثين } & \multirow{3}{*}{ الاتصال المرجعي المعرفي الزراعي } & \multirow{3}{*}{ r } \\
\hline \multicolumn{2}{|c|}{ ل ل ال يحدث } & \multicolumn{2}{|c|}{ يحدث نادراً } & \multicolumn{2}{|c|}{ يحدث أحياناً } & \multicolumn{2}{|c|}{ يحدث دائماً } & & \\
\hline$\%$ & $ت$ & $\%$ & $ت$ & $\%$ & $ت$ & $\%$ & $ت$ & & \\
\hline 10 & 5 & 10 & 5 & 20 & 10 & 60 & 30 & اللجوء للجيران لطلب مشورة زراعية. & 1 \\
\hline صفر & - & 20 & 10 & 30 & 15 & 50 & 25 & الذهاب إلي تاجر المبيدات لتتخيص مرض وطلب علاج له. & 2 \\
\hline 10 & 5 & 24 & 12 & 26 & 13 & 40 & 20 & الذهاب إلى تاجر تقاوي ومستلزمات الإنتاج الزراعي للاستشارة. & 3 \\
\hline 40 & 20 & 2 & 1 & 12 & 6 & 26 & 13 & اللجوء إلي المركز الإرشادي الزراعي لطلب المعلومات. & 4 \\
\hline 62 & 31 & 12 & 6 & 10 & 5 & 16 & 8 & مقابلة أخصائي المحاصيل لطلب استشارة زراعية. & 5 \\
\hline 60 & 30 & - & - & صفر & - & 2 & 1 & زيارة المرشد الزراعي في مكنبه. & 6 \\
\hline 100 & 50 & - & - & صفر & - & صفر & - & اللجوء إلي باحثين من محطات البحوث الزراعية. & 7 \\
\hline
\end{tabular}

المصدر : استيبان البحث، 2016، لعدد (50 مبحوثة).

جدول (10): اختبار (t) لمغنوية الفرق بين متوسطي درجات الاتصال المرجعي المعرفي الزراعي للمبحوثين

\begin{tabular}{|c|c|c|c|}
\hline قيمة معنوية t & درجات الحرية & قيمة t & اسم المتغير \\
\hline 0.01 & 148 & 5.327 & \multirow{2}{*}{ الاتصال المرجعي المعرفي الزراعي للمبحوثين } \\
\hline 0.01 & 89.51 & 5.144 & \\
\hline
\end{tabular}


جدول (11): التوزيع العددي والنسبي لمتغير الدعم الإداري للمدارس الحقلية

\begin{tabular}{|c|c|c|c|c|c|}
\hline \multicolumn{3}{|r|}{ عينة المزارعات } & \multicolumn{3}{|r|}{ عينة الزراع } \\
\hline$\%$ & عدد & فئات الدعم الإداري & $\%$ & عدد ع ا & فئات الدعم الإداري \\
\hline صفر & صفر & - منخفض ( 10 - 19 ) درجة & صفر & صفر & - منخفض ( 10 - 19 ) درجة \\
\hline صفر & صفر & - متوسط ( 20 - 29 ) درجة & 1 & 1 & - متوسط (20 - 29 ) درجة \\
\hline 100 & 50 & - مرتفع ( 30 درجة فأكثر ) & 99 & 99 & - مرتفـع ( 30 درجة فأكثر ) \\
\hline 100 & 50 & المجمــــوع & 100 & 100 & المجمــــوع \\
\hline \multicolumn{2}{|c|}{36.96} & المتوسط الحسابي & \multicolumn{2}{|c|}{37.76} & المنوسط الحسابي \\
\hline \multicolumn{2}{|c|}{3.28} & الانحراف المعياري & \multicolumn{2}{|c|}{2.74} & الانحراف المعياري \\
\hline
\end{tabular}

المصدر : استيبان البحث، 2016، لعدد (100 مزارع مبحوث، 50 مبحوثة).

وبمقارنة استجابات المزارعات المبحوثات وفقاً لتكرارات أرائهن في الدعم الإداري المقدم للمدارس الحقليـة التي

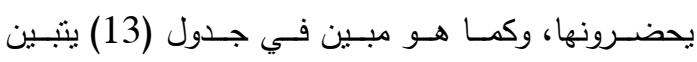

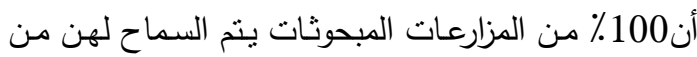

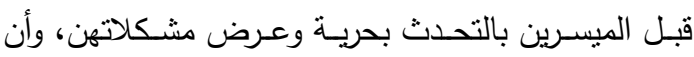
98 منهن أفدن بأنه يتم تحديد المسئولين لموقع ومكان مناسب وغير بعيد، وأن 92\% منهن أفدن بأنهن لا يتركن

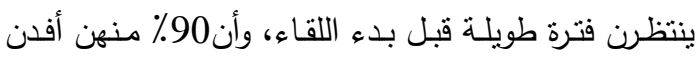

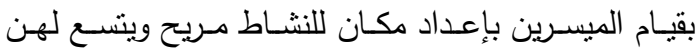

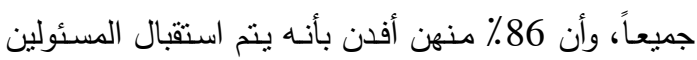
لهن بحفاوة وترحاب، وأن 78٪ من منهن أفدن بأن المسئولين

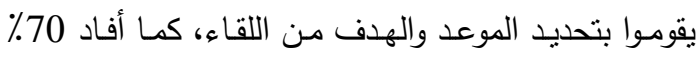

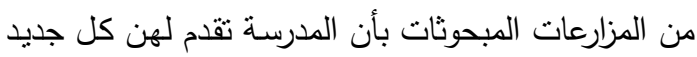

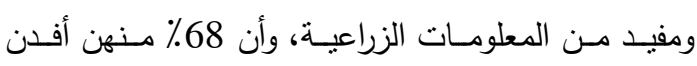
بتقديم معلومات زراعية نساهم في حل مشكلات فعلية لاي

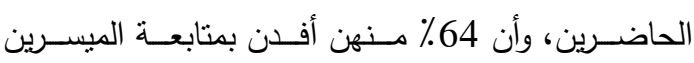
للحاضرين منهن أثناء تطبيق ما تعلموه في حقولهم، وأخيراً

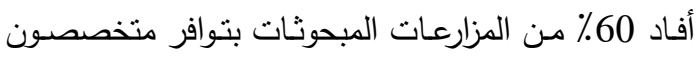

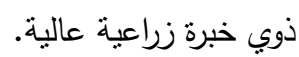

وباستعراض تكرارات استجابات الزراع المبحوثين وفقاً لأرائهم في الدعم الإداري المقدم للمدارس الحقليـة التـي

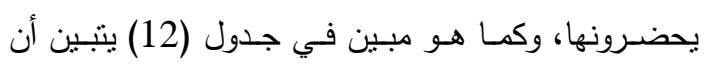
94\% مـن الـزراع المبحــثين أفـادوا باسـتقبال المسئولين للمدعوين بحفاوة وترحاب، وأفاد 91\% منهم بتقديم الددرسة المبن

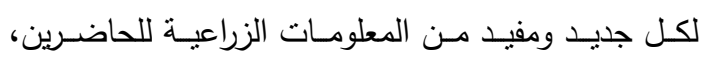
و 90 منهم أفاد بقيام المسئولين بتحديد الموعد والهدف من اللقاء، وذكر 90٪ منهم توافر متخصصين ذوب خبرة زراعية عالية، و 88٪ أفادوا بسماح الميسرين للحاضرين

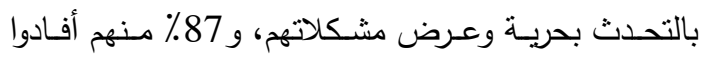
بقيام المسئولين ين بتحديد موقع ومكسان مناسـب وغير بعيد، وذكر 81\% منهم بعدم انتظار الحاضرين فترة طويلة قبل بدء اللقاء، وأفاد 88٪ من المبحوثين بقيام الميسرين

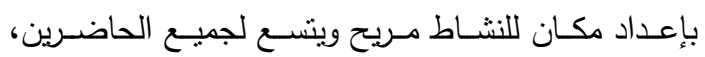

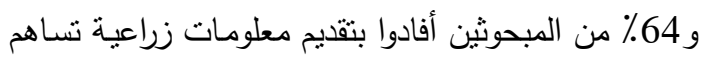

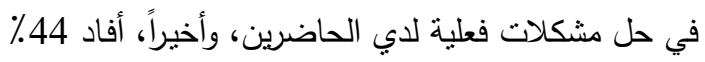
من الزراع المبحوثين بمتابعة الميسرين للحاضـرين أثناء تطبيق ما تعلموه في حقولهم. 
جدول (12): التوزيع التكراري والنسبي لمتغير الاعم الإداري للمدارس الحقلية وفقاً لآراء الزراع المبحوثين

\begin{tabular}{|c|c|c|c|c|c|c|c|c|c|}
\hline \multicolumn{8}{|c|}{ ت تكرارات استجابات المبحوثين } & \multirow{3}{*}{ 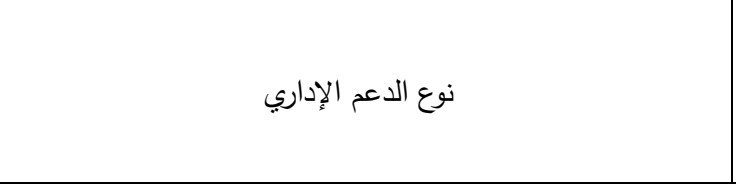 } & \multirow{3}{*}{ r } \\
\hline \multicolumn{2}{|c|}{ 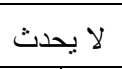 } & \multicolumn{2}{|c|}{ يحدث نادراً } & \multicolumn{2}{|c|}{ يحدث أحياناً } & \multicolumn{2}{|c|}{ يحدث دائماً } & & \\
\hline$\%$ & ت & $\%$ & $ت$ & $\%$ & $ت$ & $\%$ & $ت$ & & \\
\hline- & - & 1 & 1 & 5 & 5 & 94 & 94 & استقبال المسئولين للمدعوين بحفاوة وترحاب. & 1 \\
\hline- & - & - & - & 9 & 9 & 91 & 91 & تقديم المدرسة لكل جديد ومفيد من المعلومات الزراعية للحاضرين. & 2 \\
\hline- & - & - & - & 10 & 10 & 90 & 90 & قيام المسئولين بتحديد الموعد والهدف من اللقاء. & 3 \\
\hline- & - & 1 & 1 & 9 & 9 & 90 & 90 & توافر متخصصين ذوي خبرة زراعية عالية. & 4 \\
\hline- & - & - & - & 12 & 12 & 88 & 88 & سماح الميسرين للحاضرين بالتحدث بحرية وعرض مشكلاتهم. & 5 \\
\hline- & - & - & - & 13 & 13 & 87 & 87 & قيام المسئولين بتحديد موقع ومكان مناسب وغير بعيد. & 6 \\
\hline 1 & 1 & 1 & 1 & 17 & 17 & 81 & 81 & عدم انتظار الحاضرين فترة طويلة قبل بدء اللقاء. & 7 \\
\hline- & - & - & - & 20 & 20 & 80 & 80 & قيام الميسرين بإعداد مكان للنشاط مريح ويتسع لجميع الحاضرين. & 8 \\
\hline- & - & 1 & 1 & 35 & 35 & 64 & 64 & |تقديم معلومات زراعية تساهم في حل مشكلات فعلية لدي & 9 \\
\hline 7 & 7 & 13 & 13 & 36 & 36 & 44 & 44 & منابعة المبسرين للحاضرين أثناء تطبيق ما تعلموه في حقولهم . & 10 \\
\hline
\end{tabular}

جدول (13): التوزيع التكراري والنسبي لمتغير الدعم الإداري للمدارس الحقلية وفقاً لآراء المزارعات المبحوثات

\begin{tabular}{|c|c|c|c|c|c|c|c|c|c|}
\hline \multicolumn{8}{|c|}{ تكرارات استجابات المبحوثين } & \multirow{3}{*}{ 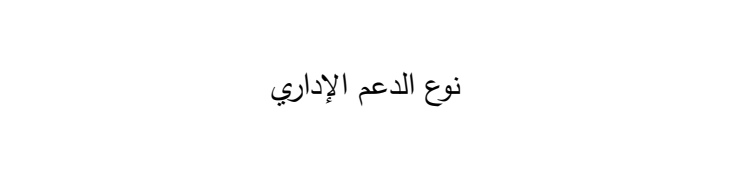 } & \multirow{3}{*}{ s } \\
\hline \multicolumn{2}{|c|}{ لا يحدث } & \multicolumn{2}{|c|}{ 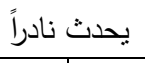 } & \multicolumn{2}{|c|}{ بحدث أحياناً } & \multicolumn{2}{|c|}{ 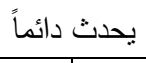 } & & \\
\hline$\%$ & عدد & $\%$ & عدد & $\%$ & عدد & $\%$ & عدد & & \\
\hline- & - & - & - & - & - & 100 & 50 & سماح الميسرين للحاضرين بالتحدث بحرية وعرض مشكلاتهم. & 1 \\
\hline 2 & 1 & - & - & - & - & 98 & 49 & قيام المسئولين بتحديد موقع ومكان مناسب وغير بعيد. & 2 \\
\hline 4 & 2 & - & - & 4 & 2 & 92 & 46 & عدم انتظار الحاضرين فترة طويلة قبل بدء اللقاء. & 3 \\
\hline- & - & - & - & 10 & 5 & 90 & 45 & قيام الميسرين بإعداد مكان للنشاط مريح ويتسع لجميع الحاضرين. & 4 \\
\hline- & - & 2 & 1 & 12 & 6 & 86 & 43 & استقبال المسئولين للمدعوين بحفاوة وترحاب. & 5 \\
\hline 20 & 10 & - & - & 2 & 1 & 78 & 39 & قيام المسئولين بتحديد الموعد والهدف من اللقاء. & 6 \\
\hline- & - & 4 & 2 & 26 & 13 & 70 & 35 & تقديم المدرسة لكل جديد ومفيد من المعلومات الزراعية للحاضرين. & 7 \\
\hline 4 & 2 & 8 & 4 & 20 & 10 & 68 & 34 & تقديم معلومات زراعية تساهم في حل مشكلات فعلية لدي الحاضرين. & 8 \\
\hline 4 & 2 & 20 & 10 & 12 & 6 & 64 & 32 & متابعة الميسرين للحاضرين أثناء تطبيق ما تعلموه في حقولهم. & 9 \\
\hline- & - & 8 & 4 & 32 & 16 & 60 & 30 & توافر متخصصين ذوي خبرة زراعية عالية. & 10 \\
\hline
\end{tabular}

المصدر : استبيان البحث، 2016، لعدد (50 مبحوثة).

(Test

متوسطين، كما هو موضح بجدول (14) ماهن

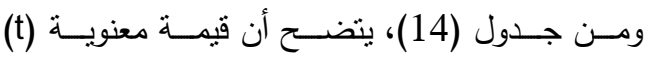

المحسوبة أكبر من 0.05 وهذا معناه عدم وجود فروق
وللتحقق من عدم وجود فروق جوهريـة بين متوسطي

درجات الدعم الإداري المقدم للمدارس الحقلية لمجموعتي

t-) الزراع والمزارعـات المبحـوثين، تم الإسـتعانة باختبـار 
من المزارعات المبحوثات، وأن نسبة ذوى الاتجاه المحايد

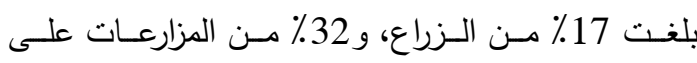

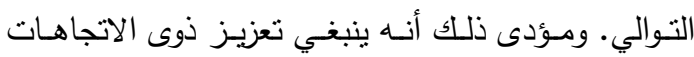
المحايدة لتكون إيجابية، حتى يمكن تعظيم استفادتهم من المدارس الحقلية المنفذة لصالحهم.

وللتحقق من عدم وجود فروق جوهريـة بين منوسطي درجات اتجاهات مجموعتي الزراع والمزارعات المبحوثين نحو المدارس لحقليـة، تم الإنـتعانة باختبـار (t-Test)

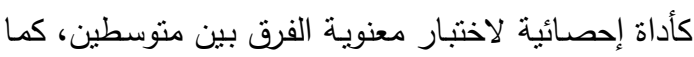
هو موضح بجدول (16).
معنويــة بـين متوسـطي درجـات الـــم الإداري الدقــدم

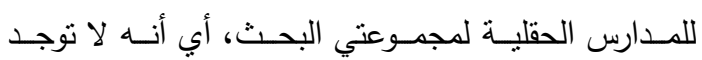

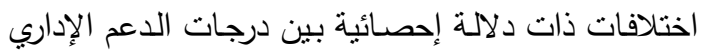

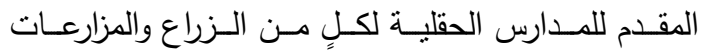
المبحوثين. وأنه بعتمد على النتائج البحثية التي تم التوصل

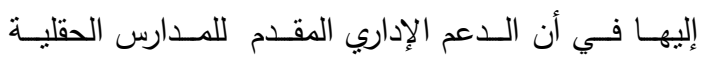

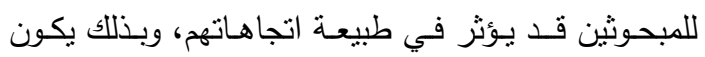
الهدف الثاني للبحث، قد تحقق جزئياً.

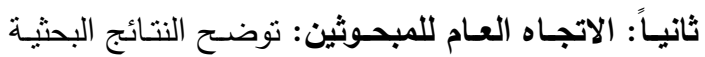
الـواردة في جدول (15) أن 83٪ مـن الزراع المبحوثين

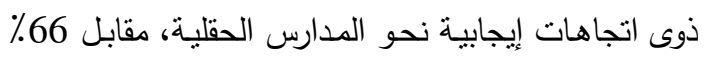

جدول (14): اختبار (t) لمعنوية الفرق بين متوسطي درجات الدعم الإداري للمدارس الحقلية لمجموعتي المبحوثين

\begin{tabular}{|c|c|c|c|}
\hline قيمة معنوية t & درجات الحرية & قيمة t & اسم المتغير \\
\hline 0.117 & 148 & 1.578 & \multirow{2}{*}{ لدعم الإداري المقدم للمدارس الحقلية } \\
\hline 0.141 & 84.126 & 1.486 & \\
\hline
\end{tabular}

جدول (15): التوزيع العددي والنسبي لمتغير اتجاهات المبحوثين نحو المدارس الحقلية

\begin{tabular}{|c|c|c|c|c|c|}
\hline \multicolumn{3}{|r|}{ عينة المزارعات } & \multicolumn{3}{|r|}{ عينة الزراع } \\
\hline$\%$ & عدد & فئات طبيعة الاتجاه & $\%$ & عدد & فئات طبيعة الاتجاه \\
\hline 2 & 1 & - سلبي ( 15 - 24 ) درجة & صفر & صفر & - سلبي ( 15 - 24 ) درجة \\
\hline 32 & 16 & - محايد ( 25 - 34 ) درجة & 17 & 17 & - محايد ( 25 - 34 ) درجة \\
\hline 66 & 33 & - إيجابي ( 35 درجة فأكثر ) & 83 & 83 & - إيجابي ( 35 درجة فأكثر ) \\
\hline 100 & 50 & المجمــــوع & 100 & 100 & المجمــــوع \\
\hline \multicolumn{2}{|c|}{35.20} & المتوسط الحسابي & \multicolumn{2}{|c|}{39.4} & المتوسط الحسابي \\
\hline \multicolumn{2}{|c|}{4.54} & الانحراف المعياري & \multicolumn{2}{|c|}{4.01} & الانحراف المعياري \\
\hline
\end{tabular}

المصدر : استيان البحث، 2016، لعدد (100 مزارع مبحوث، 50 مبحوثة).

جدول (16): اختبار (t) لمعنوية الفرق بين متوسطي درجات الاتجاه العام لمجموعتي المبحوثين نحو المدارس الحقلية

\begin{tabular}{|c|c|c|c|}
\hline قيمة معنوية t & درجات الحرية & قيمة t & اسم المتغير \\
\hline 0.01 & 148 & 5.781 & \multirow{2}{*}{ الاتجاه العام نحو الددارس الحقلية } \\
\hline 0.01 & 87.979 & 5.544 & \\
\hline
\end{tabular}




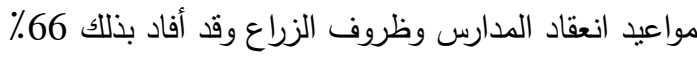

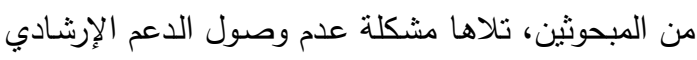

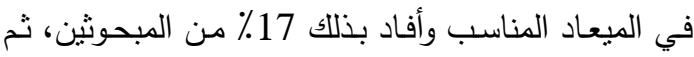
مشكلة عدم الاهتمام بتجهيز مكان المدرسة بشكلٍ مناسب وأفاد بذلك 14\% من المبحوثين.

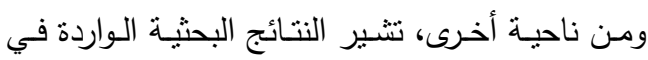
جدول (18) إلى بعض الشكلات التي تواجه المزارعات المبحوثات أثثـاء انعقـاد المـارس الحقليـة، أمكن ترتيبها

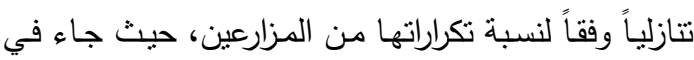
مقدمتها التعارض بين مواعيد انعقاد المدارس والانثـغال

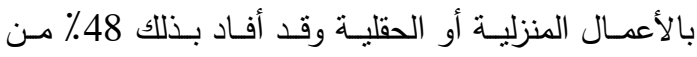

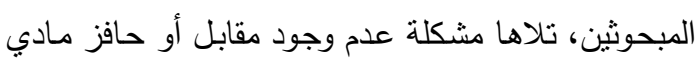

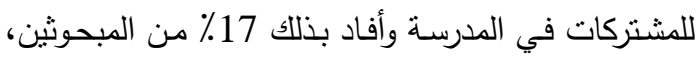

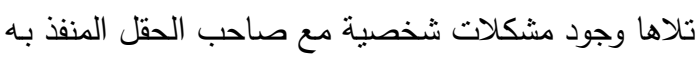
المدرسة الحقلية وأفاد بذلك 10٪ من المبحوثات.

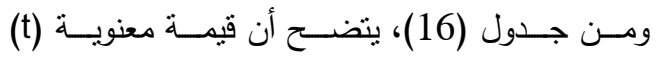
المحسوبة أقل من 0.05 وهذا معناه وجود فروق معنوية بين متوسطي درجات الاتجاه العام لهجموعتي البحث، أي أنه توجد اختلافات ذات دلالة إحصائية بين درجات اتجاه

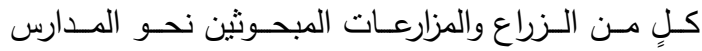

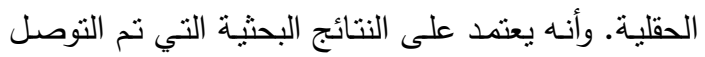
إليهـا في أنـهـ يوجـــ فـروق معنويـة بـين الاتجـاه العـام

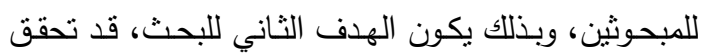

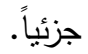

ثالثاً: المشكلات التـي تواجـه زراع ومزارعـات المـارس الحقلية:

تشير النتائج البحثية الواردة في جدول (17) إلى وجود بعض المشكلات التي تواجه الزراع المبحوثين أثناء انعقاد

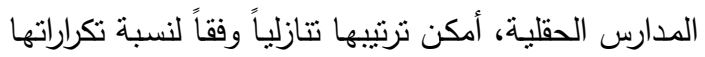
من قبل المبحوثين، حيث جاء في مقدمتها النعارض بين

جدول (17): التوزيع التكراري للمشكلات التي تواجه الزراع أثناء انعقاد المدارس الحقلية

\begin{tabular}{|c|c|c|c|}
\hline$\%$ & 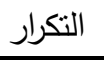 & 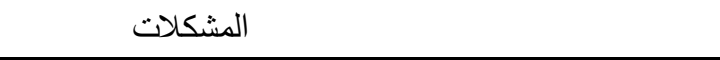 & 5 \\
\hline 66 & 66 & التعارض بين مواعيد انعقاد المدرسة وظروف بعض الزراع. & 1 \\
\hline 17 & 17 & عدم وصول الدعم الإرشادي في الميعاد المناسب. & 2 \\
\hline 14 & 14 & عدم الاهتمام بتجهيز مكان المدرسة بشكل مناسب. & 3 \\
\hline 8 & 8 & عدم توفر المعينات الإرشادية مثل المطبوعات والنشرات. & 4 \\
\hline 6 & 6 & بدء المدارس الحقلية مع بداية خدمة الأرض للمحصول. & 5 \\
\hline 4 & 4 & عدم تغطية المدارس الحقلية لكل المحاصيل. & 6 \\
\hline
\end{tabular}

جدول (18): التوزيع التكراري للمشكلات التي تواجه المدارس الحقلية من وجهة نظر الزراع المبحوثين

\begin{tabular}{|c|c|c|c|}
\hline$\%$ & التكرار & 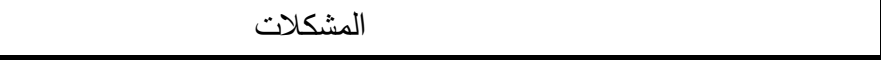 & م \\
\hline 48 & 24 & التعارض بين مواعيد انعقاد المدرسة والانشغال في أعمال المنزل أو الحقل. & 1 \\
\hline 24 & 12 & عدم وجود مقابل أو حافز مادي للمشتركات في المدرسة. & 2 \\
\hline 10 & 5 & وجود مشاكل شخصية مع صاحب الحقل المنفذ به الددرسة الحقلية. & 3 \\
\hline 8 & 4 & المشاكل التي تتسبب فيها الأطفال أثثاء المدرسة الحقلية. & 4 \\
\hline 8 & 4 & تسلط الزوج أو الابن أو الحماة. & 5 \\
\hline
\end{tabular}


المزارعــة المبحوثـة، ومسـتواها التعليــي، واتصــالها بالمصادر المرجعية المعرفية الزراعية، والدعم الإداري

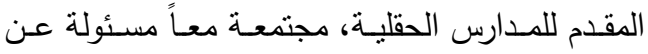
تفسير 74.1٪ من جملة التغيرات التي يمكن حدوثها

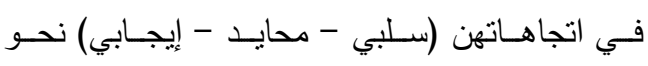

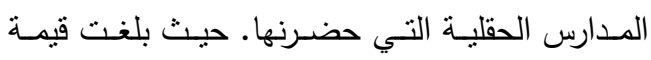
Coefficient of Determination معامل التحديد

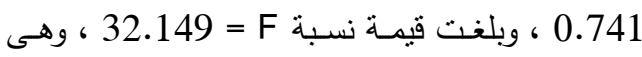

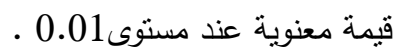

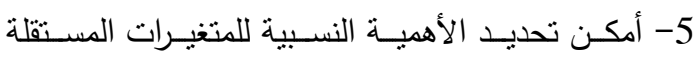

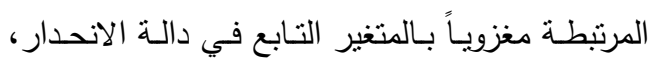

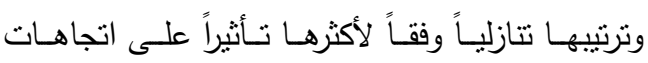
المبحوثين نحو المـارس الحقليـة - كتثغير تـابع -

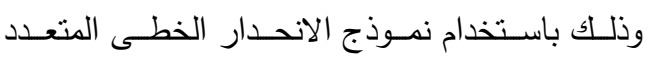

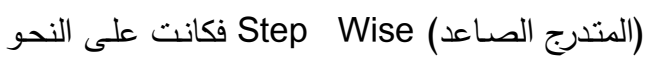
التالي:

أ- - بالنسبة للزراع المبحوثين، تبين أن متغيراً واحداً، وهو :

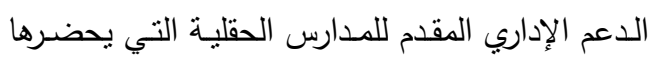

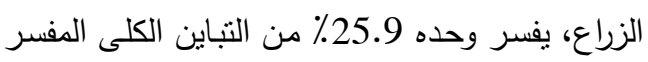

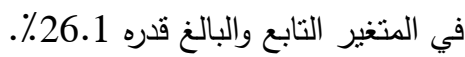

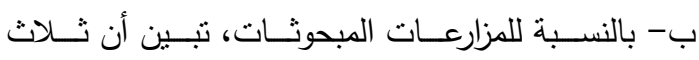

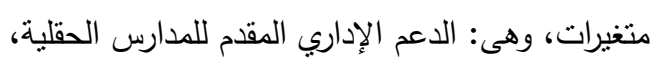

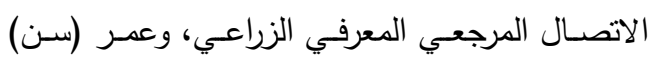

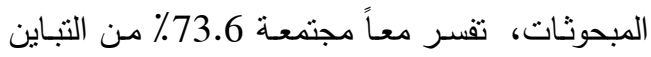
الكلى المفسر في المتغير التابع، وذلك بالنسب التالية:

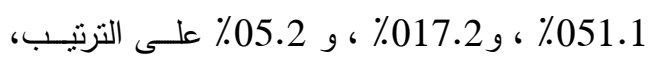
كما هو موضـح في جدول (19). وتتطوي البيانات

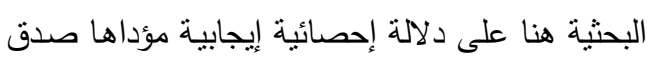

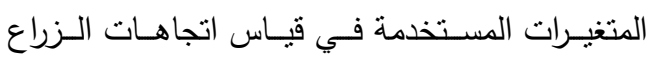

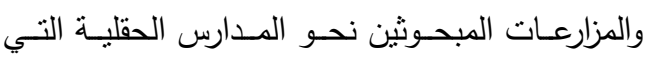

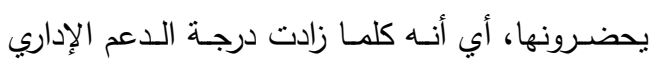

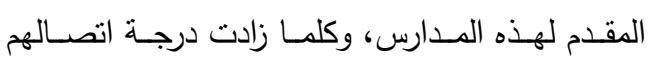

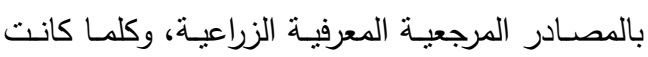

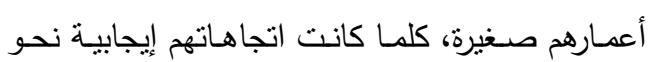

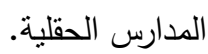

رابعـاً: بعض المتغيـرات التـي تـؤثر علـى الاتجـاه العـام للمبحوثين نحو المدارس الحقلية:

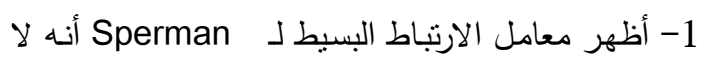
توجد علاقة مغزوية بين المتغير المستقل غير الخطى الإنى

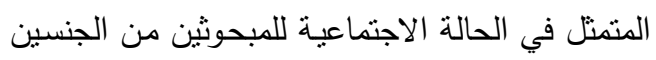

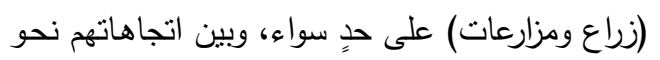

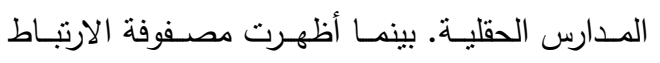
البسيط لـ Person أن متغيرين مستقلين خطيين، وهمـا: الاتصـال المرجعي المعرفي الزراعي، والداعم الإداري المقدم للمــارس الحقليـة، يرتبطــان ارتباطـاً

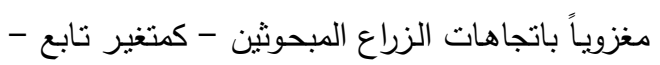
عند مسنوى معنوية 0.05 ، و 0.01 على النزتيب.

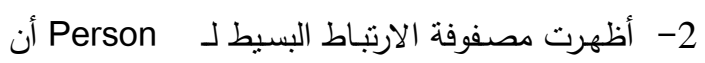
ثلاث متغيرات مستقلة خطية، وهـى: أعمـار (سن)

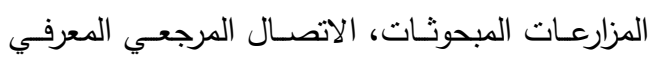
الزراعي لهن، والدعم الإداري المقدم للمدارس الحقلية،

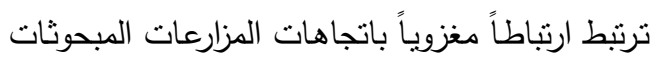

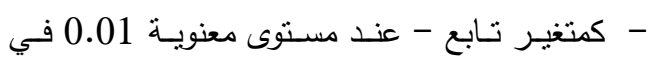
الثناث متغيرات. 3- تبين من قيمـة معامل الانحدار الجزئي القياسي أن

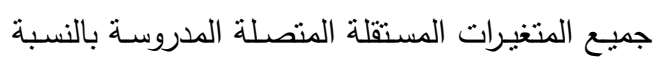

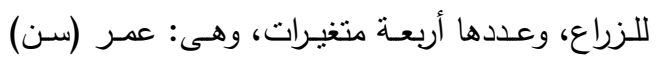

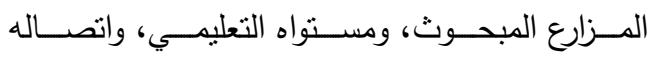
بالمصادر المرجعية المعرفية الزراعية، والدعم الإداري

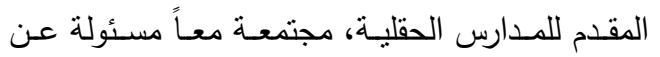
تفسير 26.1\% من جملة التغيرات التي يمكن حدوثها

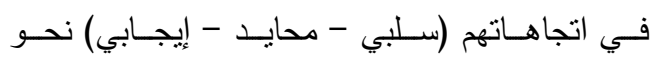

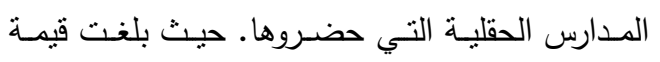
Coefficient of Determination معامل التحديد

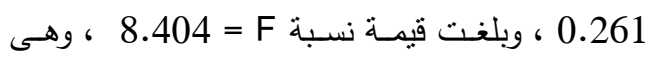
قيمة معنوية عند مستوى01010 0.261. 4- نبين مـن قيمـة معامـل الانحدار الجزئي القياسـي أن

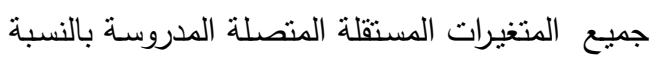
للمزارعات، وعددها أربعة متغيرات، وهى: عمر (سن) 
جدول (19): نتائج تحليل نموذج الانعار الخطى المتعدد (المتدرج الصاعد) Step Wise

\begin{tabular}{|c|c|c|c|c|c|c|c|}
\hline المعنوية & نسبة قيمة & اللتياسي & التحديد & معامل التحديد & الارتباط & الأهمية النسبية للمتغيرات & العينة البحثية \\
\hline 0.01 & 34.318 & 3.4687 & 0.252 & 0.259 & 0.509 & 1- الدعم الإداري المقدم للمدارس الحقلية. & 1- عينة الزراع \\
\hline 0.01 & 50.117 & 3.2116 & 0.501 & 0.511 & 0.715 & 1- الدعم الإداري المقدم للمدارس الحقلية. & \\
\hline 0.01 & 50.620 & 2.6128 & 0.669 & 0.683 & 0.826 & 2- الاتصال المرجعي المعرفي الزراعي. & 2- عينة المزارعات \\
\hline 0.01 & 42.707 & 2.4096 & 0.719 & 0.736 & 0.858 & 3- الأعمار (السن). & \\
\hline
\end{tabular}

والأرز والذرة) بمحافظات الإسكندرية والبحيرة والغربية، نشرة بحثية رقم (239)، معهد بحوث الإرشاد الزراعي الجئي

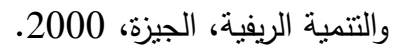

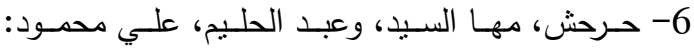

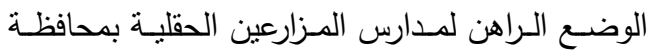

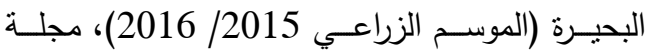

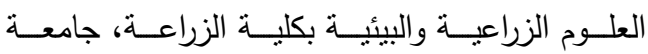

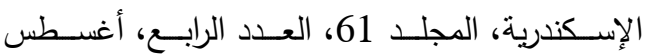
.2016

7- رافع، حمدى السيد أنور، الفيشاوى، طه محمد،

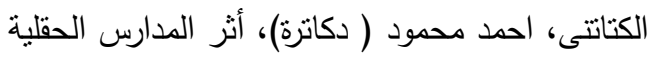

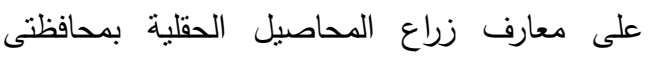
سوهاج وأسيوط، مجلة حوليات العلوم الزراعية بمشتهر ، مجلد 14، العدد 1، .2003 حسلة

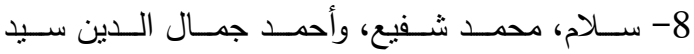
(دكتوران): بعضض العوامـل المـؤثرة علـى اتجاهـات

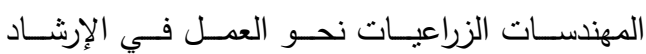
الزراعي، نشرة بحثية رقم (26)، معهد بحوث الإرشاد

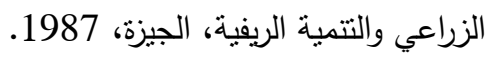
9- عتمان، محمود إسماعيل: دراسة تحليلية لعملية انتشار التوصيات الإرشادية بين زراع الأرز بمركز المحمودية دئية

بمحافظة البحيرة، .1989)

10- Krech, and R.S. Crutechfeld (1948). Theory and problems of Social Physiology. McGraw Hill Book Comp. Bombay.

11- Maunder, A.H. (1973). Agricultural Extension: A reference manual, (abridged Edition), Food and Agricultural Organization of the United Nations, Rome.
خامساً: التوصيات البحثية:

في ضوء النتائج البحثية، فإنه يمكن التوصية التوصية بما يلي: 1- زيادة الدعم الإداري الدقدم للمدارس الحقلية.

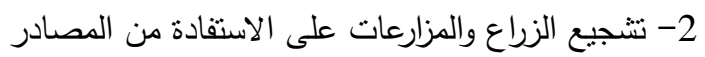

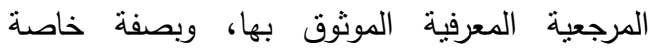
العاملين بالإرشاد الزراعي والبحوث الزراعية. 3- اختيار زراع المدارس الحقلية من الفئات العمرية المناسبة لأنشطة الددارس الحقلية.

1- الإدارة المركزيــة للإرشــاد الزراعسى: دليـل الإرشــاد

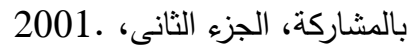

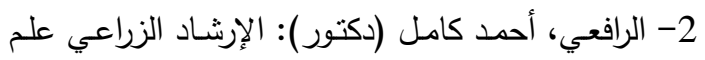

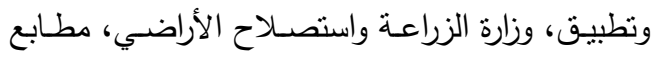
مركز الدعم الإعلامي، مريوط، 1993.

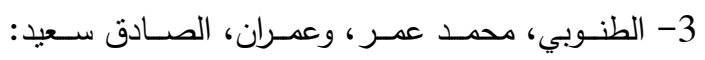

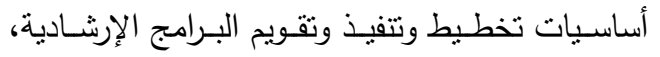
جامعة عمر المختار ، البيضاء، 1997.

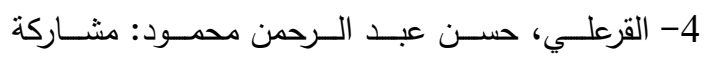
الهـزارعين فـي مجموعـات العمـل الحقليـة الإرشـادية بمحافظة الإسماعيلية (دراسـة عن المدارس الحقلية)،

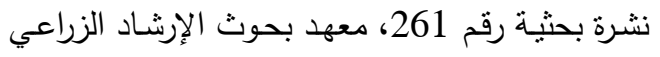
والتتمية الريفية، مركز البحوث الزراعية، وزارة الزراعة الزية

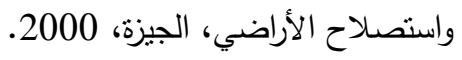

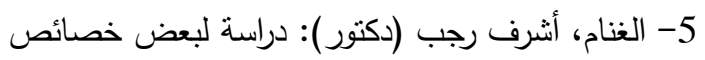

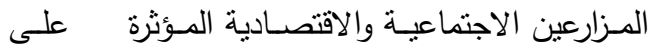

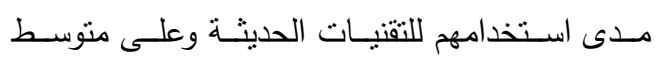
إنتاجيتهم الزراعية للمحاصيل الرئيسية (القطن والقمح 
U.S.A, 1970.

\title{
SOME FACTORS AFFECTING IN THE ATTITUDES OF FARMERS TOWARDS THE FIELD SCHOOLS IN EI-BEHERA GOVERNORATE
}

\author{
Maha E. Harhash and A. M. Abdel-Halim \\ Department of Agric. Economic, Extension and Rural Development, Faculty of Agriculture, \\ Damanhur University.
}

\begin{abstract}
This research aimed mainly to identify some factors affecting on the farmers' attitudes towards the field schools in El-Behera governorate. There are two populations of the research, one of them to the farmers its size is 200 farmers, the second are for female farmers its size 100 beneficiaries of agricultural extension activities of the FFS, amounted to 12 field school which have been implemented in four districts in El-Behera Governorate, they are Damanhur, El-Mahmoudia, Abou-Houmos and Kafr-Eldawar, during the agricultural year of $2015 / 2016$, the sample was selected randomly from each populations on by $50 \%$. The research sample amounted to 150 respondents (100 farms +50 women's farmers).

Data were collected using an interviewing questionnaire during the months of April and May 2016. The descriptive statistics such as, frequency tables, arithmetic means, standard deviation, Pearson's simple correlation coefficient, and the Indicative statistics such as, Multiple Correlation and Regression Step-Wise, and t-test, were used as statistical tools to explain and interpret the results.
\end{abstract}

The main results were as follows:

1-Ages of the respondents: 55\% of the respondent's farmers ranged between 36-53 years, versus with $40 \%$ of respondent's farmers' women.

2- Education of respondents: 12\% of respondents farmers are illiterate versus 58\% approximately of respondents' farmers' women this result, agree with rural traditions of the interest of the education of male children greater degree than the female.

3- Marital status: $91 \%$ of respondent's farmers are married versus $86 \%$ approximately of respondents' farmers' women.

4- Communication with the resources of agricultural knowledge Reference: $62 \%$ of respondents' farmers were have had moderate Communication with resources of agricultural knowledge Reference while getting their agricultural information, versus $62 \%$ approximately of respondents' farmers' women. It is a logical consequence in light of the communicational customs and traditions in the Egyptian countryside nowadays.

5- Administrative support to the field schools: $99 \%$ of respondents' farmers reported that degree to take the necessary procedures to complete the field schools by officials (facilitators) was big degree, versus about $100 \%$ of the respondents' farmers' women.

6- The general Attitude of the respondents towards the field schools: $83 \%$ of respondent's farmers were positive Attitude towards the field schools, versus $66 \%$ of respondent's farmers. This means that the most of farmers and farmers' women respondents were positive Attitude towards the field farmer schools.

7- Problems facing the field schools: respondents' farmers reported that some problems they face while participating in the field school, it came in the forefront of them: inconsistency between school holding and circumstances of some farmers, Non-arrival extension support at the appropriate time and lack of attention to the processing place of the school as well. The problems facing the farmer's women were: busy at home, work or field, Lack of incentive or a fee, and having personal problems with the field school owner.

8- Significant difference between respondents Attitudes: There are no statistically significant differences in the Attitudes of the two groups of farmers and farmers' women respondents towards the field farmer's schools.

Key words: attitudes - farmers - farmers' women -the field schools - El-Behera Governorate 